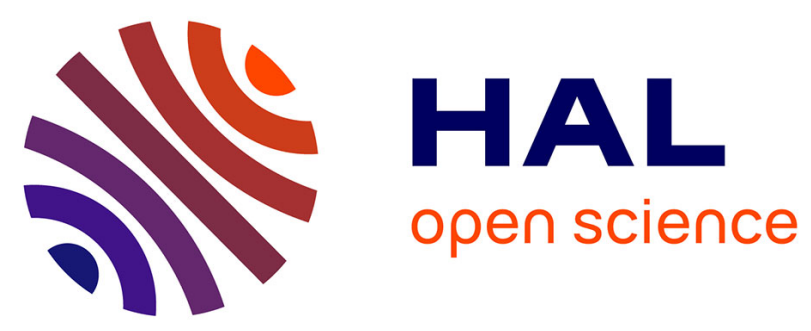

\title{
Kinetic Analysis of the Immortal Ring-Opening Polymerization of Cyclic Esters: A Case Study with Tin(II) Catalysts
}

Lingfang Wang, Valentin Poirier, Fabio Ghiotto, Manfred Bochmann, Roderick D. Cannon, Jean-François Carpentier, Yann Sarazin

\section{To cite this version:}

Lingfang Wang, Valentin Poirier, Fabio Ghiotto, Manfred Bochmann, Roderick D. Cannon, et al.. Kinetic Analysis of the Immortal Ring-Opening Polymerization of Cyclic Esters: A Case Study with Tin(II) Catalysts. Biomacromolecules, 2014, 47 (8), pp.2574-2584. 10.1021/ma500124k . hal01114346

HAL Id: hal-01114346

https://hal-univ-rennes1.archives-ouvertes.fr/hal-01114346

Submitted on 15 Dec 2021

HAL is a multi-disciplinary open access archive for the deposit and dissemination of scientific research documents, whether they are published or not. The documents may come from teaching and research institutions in France or abroad, or from public or private research centers.
L'archive ouverte pluridisciplinaire HAL, est destinée au dépôt et à la diffusion de documents scientifiques de niveau recherche, publiés ou non, émanant des établissements d'enseignement et de recherche français ou étrangers, des laboratoires publics ou privés. 


\title{
Kinetic Analysis of the Immortal Ring-Opening Polymerization of Cyclic Esters:
}

\section{A Case Study with Tin(II) Catalysts}

\author{
Lingfang Wang, ${ }^{\dagger}$ Valentin Poirier, ${ }^{\dagger}$ Fabio Ghiotto, ${ }^{\dagger}$ Manfred Bochmann,,$*$ \\ Roderick D. Cannon, ${ }^{*}, \dot{\dagger}$ Jean-François Carpentier ${ }^{*, \dagger}$ and Yann Sarazin ${ }^{*, \dagger}$
}

Email addresses: m.bochmann@uea.ac.uk; r.cannon@uea.ac.uk; jean-francois.carpentier@univrennes1.fr; yann.sarazin@univ-rennes1.fr

$\dagger$ Organometallics: Materials and Catalysis, Institut des Sciences Chimiques de Rennes, UMR 6226 CNRS - Université de Rennes 1, Campus de Beaulieu, 35042 Rennes Cedex, France.

$\ddagger$ Wolfson Materials and Catalysis Centre, School of Chemistry, University of East Anglia, Norwich NR4 7TJ, UK.

\begin{abstract}
A kinetic analysis of the metal-catalyzed immortal ring-opening polymerization (ROP) of cyclic esters is presented, based on a first-principles approach without making assumptions regarding the active species. The kinetics of all immortal ROP reactions performed with a metal catalyst and an exogenous chain transfer agent are characterized by the initiation, propagation and exchange rate constants $\left(k_{\mathrm{i}}, k_{\mathrm{p}}\right.$ and $k_{\mathrm{e}}$, respectively). Curve fitting to this kinetic scheme in the initial stage of the polymerization allows the extraction of $k_{\mathrm{i}}$ and $k_{\mathrm{p}}$ from a single experiment. This has been illustrated for the ROP of L-lactide using tin(II) complexes of the type $\left\{\mathrm{LO}^{i}\right\} \mathrm{Sn}(\mathrm{X})\left(\left\{\mathrm{LO}^{i}\right\}=\right.$ aminophenolate ancillary ligand, $\mathrm{X}=\mathrm{N}\left(\mathrm{SiMe}_{3}\right)_{2}$ or methyl $(S, S)$-lactate $), \mathrm{Sn}(\mathrm{O} i \mathrm{Pr})_{2}$ or $\mathrm{Sn}\left(\mathrm{N}\left(\mathrm{SiMe}_{3}\right)_{2}\right)_{2}$ as precatalysts paired with excess $i \mathrm{PrOH}$ as a co-activator. Non-linear regressions $\left(R^{2}>0.999\right)$
\end{abstract}


illustrate the three possible scenarios, $k_{\mathrm{i}}<k_{\mathrm{p}}, k_{\mathrm{i}}=k_{\mathrm{p}}$ and $k_{\mathrm{i}}>k_{\mathrm{p}}$. The kinetic model can be extended to any metal (pre)catalyst for the immortal ROP of any cyclic ester, as exemplified using trimethylene carbonate as a monomer or employing a germylene precatalyst. A kinetic treatment for the late phase of immortal ROP reactions is introduced, which also gives direct access to $k_{\mathrm{p}}$. In agreement with the ROP kinetic data for $\left\{\mathrm{LO}^{i}\right\} \mathrm{Sn}\left(\mathrm{N}\left(\mathrm{SiMe}_{3}\right)_{2}\right), \mathrm{Sn}(\mathrm{OiPr})_{2}, \mathrm{Sn}\left(\mathrm{N}\left(\mathrm{SiMe}_{3}\right)_{2}\right)_{2}$ and the new $\mathrm{Sn}(\mathrm{OiPr})\left(\mathrm{N}\left(\mathrm{SiMe}_{3}\right)_{2}\right.$ recorded in the presence of various quantities of $i \mathrm{PrOH}$, synthetic and ${ }^{119} \mathrm{Sn}\left\{{ }^{1} \mathrm{H}\right\}$ NMR data provide evidence for reversible production of tin(II) bis(alkoxide) when a small excess (1-3 equiv) of alcohol is used with tin(II) precatalysts. It is also shown that, regardless of the identity of the precatalyst, $\mathrm{Sn}(\mathrm{OiPr})_{2}$ and $\mathrm{Sn}(\mathrm{O}-\text { polymeryl })_{2}$ are, respectively, the actual initiating and propagating species when immortal ROP reactions are performed in the presence of a larger excess of alcohol (7 equiv or more $v s . \mathrm{Sn})$.

\section{Introduction}

The ring-opening polymerization (ROP) of lactide, $\varepsilon$-caprolactone, $\beta$-butyrolactone or trimethylene carbonate continues to receive growing interest because some of these cyclic esters are derived from biomass and the resulting biocompatible materials offer an attractive range of physical properties. ${ }^{1}$ The number of key studies ${ }^{2}$ and review articles ${ }^{3}$ covering the design of metal catalysts enabling controlled, and often living, ROP reactions is a testimony to the health of the field. The step from academic laboratory to industrial plants is now a key item on the agenda. In this aim, so-called “immortal” ROP processes, known since the 1980's for oxiranes, ${ }^{4}$ offer real promise. Unlike regular living polymerizations where each metal centre produces only one polymer chain during the entire process, the use of an inexpensive chain transfer agent (typically an alcohol) in immortal polymerizations ${ }^{5}$ allows the production of many macromolecules per catalyst through reversible chain transfer between growing and dormant polymer chains. ${ }^{3 \mathrm{~d}, 6}$ The advantages of such reactions have attracted attention, ${ }^{7}$ and efforts are being made to implement them under industrial 
conditions. ${ }^{8}$ Yet, the mechanisms of these reactions, and in particular the kinetic aspects, remain rather obscure.

In spite of all the achievements in terms of catalyst development, industrial processes still rely on tin(II) species such as $\mathrm{Sn}^{\mathrm{II}}\left(2\right.$-ethyl-hexanoate) ${ }_{2} .{ }^{1,9}$ Several structurally well-defined tin(II) complexes generally featuring good performance in the polymerization of cyclic esters have also been released. ${ }^{2 \mathrm{k}, 10}$ We have used amino(ether)-phenolate tin(II) complexes to probe some of the mechanistic features of ROP reactions by ${ }^{119} \mathrm{Sn}\left\{{ }^{1} \mathrm{H}\right\}$ NMR spectroscopy and DFT computations, ${ }^{11}$ and this has led to a kinetic analysis of the (conventional) living polymerization of lactide. ${ }^{12}$

Living and immortal polymerizations represent two distinctly different mechanistic scenarios and kinetic regimes: in living ROP the polymer $M_{\mathrm{n}}$ is given by the monomer/initiator ratio, while in immortal ROP it is defined by the monomer/ROH ratio. Duda and Penczek studied in detail the influence of alcohol concentration on the rate of ROP reactions catalyzed by $\operatorname{Sn}(2$-ethylhexanoate $)_{2}$ and related catalyst precursors, and they were able to detect several trends and identify some active species. ${ }^{9}$ However, a comprehensive kinetic model has to our knowledge not been proposed for immortal polymerizations, and the simple models developed for living ROP cannot be applied to immortal systems. Tolman and Hillmyer assumed a Michaelis-Menten-type kinetic model, based on a pre-formed $\{\mathrm{L}\} \mathrm{AlO} i \mathrm{Pr}$ catalyst in the absence of added alcohol, ${ }^{13}$ and our own previous non-steady-state approach to living ROP also does not take excess alcohol into consideration. ${ }^{12}$ The description of immortal systems therefore remains mostly empirical, and kinetic analysis is confined to the determination of partial orders in monomer, (pre)catalyst and transfer agent..$^{2 r, 7,11 a}$ Yet, metallocene-catalyzed olefin polymerization has taught us the virtues of a thorough understanding of the intricacies of polymerization kinetics. ${ }^{14}$

We present here a general kinetic mechanism of the immortal polymerization of cyclic esters. Our initial attempts to identify Michaelis-Menten-type kinetic behavior in such systems were not successful, and we have therefore developed a model based simply on the known reaction steps in immortal ROP. This kinetic analysis is built on first principles only and makes no a priori 
assumptions as to the nature of the active species. In addition to the initiation $\left(k_{\mathrm{i}}\right)$ and propagation $\left(k_{\mathrm{p}}\right)$ parameters that characterize all polymerization reactions, the equations presented here take into account the exchange process (chain transfer, $k_{\mathrm{e}}$ ) specific to immortal ROP reactions.

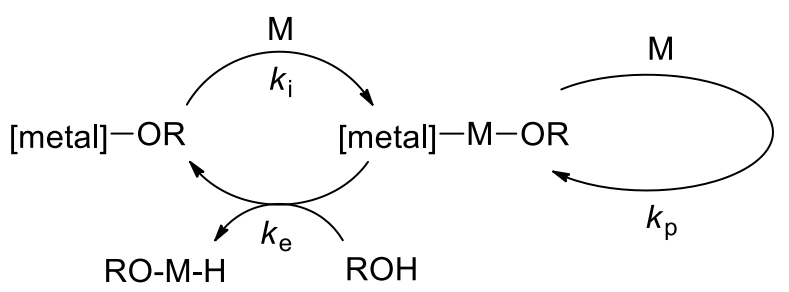

$$
\begin{aligned}
& \mathrm{M}=\text { monomer } \\
& \mathrm{ROH}=\text { alcohol chain transfer agent } \\
& k_{\mathrm{i}}=\text { initiation rate constant } \\
& k_{\mathrm{e}}=\text { alcohol exchange rate constant } \\
& k_{\mathrm{p}}=\text { propagation rate constant }
\end{aligned}
$$

The validity of the formal kinetics is then illustrated by a range of experimental data obtained during the polymerization of L-lactide or trimethylene carbonate mediated by group 14 complex / $i \mathrm{PrOH}$ binary catalysts, since these catalysts lend themselves well to kinetic monitoring (Chart 1). It is shown that non-linear regression of a single kinetic experiment allows the rapid and accurate determination of $k_{\mathrm{i}}$ and $k_{\mathrm{p}}$. The influence of the $\mathrm{ROH} / \mathrm{Sn}$ molar ratio with respect to the nature of the active species in these catalyst systems is discussed in the light of ${ }^{119} \mathrm{Sn}\left\{{ }^{1} \mathrm{H}\right\} \mathrm{NMR}$ spectroscopic and kinetic investigations.

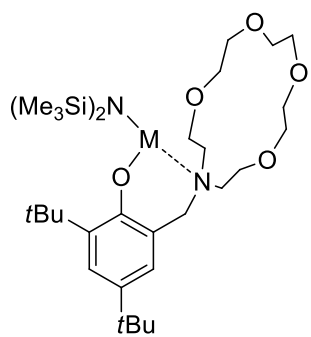

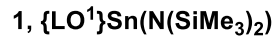

6, $\left\{\mathrm{LO}^{1}\right\} \mathrm{Ge}\left(\mathrm{N}\left(\mathrm{SiMe}_{3}\right)_{2}\right)$

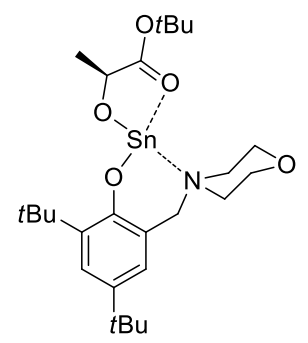

2, $\left\{\mathrm{LO}^{2}\right\} \mathrm{Sn}(\mathrm{tBu}(R)$-lactate $)$

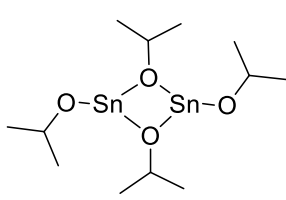

3, $\left[\mathrm{Sn}(\mathrm{OiPr})_{2}\right]_{2}$<smiles>CCN(C)[SnH]1Oc2c(cc(C(C)(C)C)cc2C(C)(C)C)CN1CC</smiles>

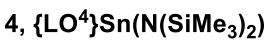

$\left(\mathrm{Me}_{3} \mathrm{Si}\right)_{2} \mathrm{~N}_{-\mathrm{Sn}}-\mathrm{N}\left(\mathrm{SiMe}_{3}\right)_{2}$

$5, \mathrm{Sn}\left(\mathrm{N}\left(\mathrm{SiMe}_{3}\right)_{2}\right)_{2}$

\section{Chart 1.}

\section{Results and Discussion}

\section{Kinetic analysis of immortal polymerizations: [ROH] >> [catalyst].}

So-called "immortal" ring-opening polymerizations of cyclic esters are performed in the presence of an alcohol $\mathrm{ROH}$ (such as isopropanol). Ring-opening and protolytic exchange reactions produce $\mathrm{OH}$-terminated macromonomers $\mathrm{R}-(\mathrm{M})_{n}-\mathrm{OH}$, with $[\mathrm{OH}]$ remaining constant throughout the 
whole process. Initially the catalyst Cat carries OR function, denoted as Cat(OR). For our kinetic mechanism we define catalyst initiation as the first insertion of monomer $M$ into a metal-alkoxide bond, characterized by the rate constant $k_{\mathrm{i}}$; this process converts $\mathrm{C}(\mathrm{OR})$ into $\mathrm{C}(\mathrm{OMR})$. Subsequent insertion steps are taken to proceed with the propagation rate $k_{\mathrm{p}}$. For simplicity it is assumed that $k_{\mathrm{p}}$ is identical for all subsequent chain growth steps. These steps are summarised in eq 1(a)-(c).

$\mathrm{Cat}(\mathrm{OR})+\mathrm{M} \rightarrow \mathrm{Cat}(\mathrm{OMR}), k_{\mathrm{i}}$

$\mathrm{Cat}(\mathrm{OMR})+\mathrm{M} \rightarrow \mathrm{Cat}\left(\mathrm{OM}_{2} \mathrm{R}\right), k_{\mathrm{p}}$

$\mathrm{Cat}\left(\mathrm{OM}_{2} \mathrm{R}\right)+\mathrm{M} \rightarrow \mathrm{Cat}\left(\mathrm{OM}_{3} \mathrm{R}\right), k_{\mathrm{p}}$

etc.

Since in an immortal polymerization an excess of $\mathrm{ROH}$ is present that interchanges with the growing polymer chain, in principle this exchange also has to be considered, eq 2(a) and 2(b). As long as unconsumed alcohol $\mathrm{ROH}$ is present, the exchange will proceed with the rate $k_{\mathrm{e}}$, which may differ from the rate $k_{\mathrm{e}}$ once all $\mathrm{ROH}$ is consumed.

$\mathrm{Cat}\left(\mathrm{OM}_{\mathrm{m}} \mathrm{R}\right)+\mathrm{HOR} \rightarrow \mathrm{HOM}_{\mathrm{m}} \mathrm{R}+\mathrm{Cat}(\mathrm{OR}), k_{\mathrm{e}}{ }^{\prime}$

$\mathrm{Cat}\left(\mathrm{OM}_{\mathrm{m}} \mathrm{R}\right)+\mathrm{HOM}_{\mathrm{n}} \mathrm{R} \rightarrow \mathrm{HOM}_{\mathrm{m}} \mathrm{R}+\mathrm{Cat}\left(\mathrm{OM}_{\mathrm{n}} \mathrm{R}\right), k_{\mathrm{e}}$

1.1 Interchange with no depletion of monomer. As shown above, the immortal ROP consumes the added alcohol $\mathrm{ROH}$ in the initial phase. However, since the exchange reactions are reversible, as long as some $\mathrm{Cat}(\mathrm{OR})$ remains, $\mathrm{ROH}$ may also be regenerated:

$\mathrm{Cat}(\mathrm{OR})+\mathrm{HOMR} \rightarrow \mathrm{Cat}(\mathrm{OMR})+\mathrm{HOR}, k_{\mathrm{e}}$

$\mathrm{Cat}(\mathrm{OR})+\mathrm{HOM}_{2} \mathrm{R} \rightarrow \mathrm{Cat}\left(\mathrm{OM}_{2} \mathrm{R}\right)+\mathrm{HOR}, k_{\mathrm{e}}$, etc.

The approximation $k_{\mathrm{e}}{ }^{\prime}=k_{\mathrm{e}}$ was considered a reasonable working hypothesis and was applied to maintain the scheme mathematically manageable. ${ }^{15}$ Note that provided $k_{\mathrm{e}}$ is sufficiently large, the 
exact value of the exchange rate constants do not impact the overall kinetics (vide infra). It can be shown (for full derivation of the kinetic model, see Supporting Information) that:

$$
\begin{aligned}
& {[\mathrm{Cat}(\mathrm{OR})]=\frac{\left(k_{\mathrm{e}}[\mathrm{Cat}]_{\mathrm{T}}+\lambda_{1}\right) \lambda_{2} \mathrm{e}^{\lambda_{1} t}-\left(k_{\mathrm{e}}[\mathrm{Cat}]_{\mathrm{T}}+\lambda_{2}\right) \lambda_{1} \mathrm{e}^{\lambda_{2} t}}{k_{\mathrm{e}}\left(\lambda_{2}-\lambda_{1}\right)}} \\
& {[\mathrm{ROH}]=\frac{\left(\lambda_{2} \mathrm{e}^{\lambda_{1} t}-\lambda_{1} \mathrm{e}^{\lambda_{2} t}\right)}{\lambda_{2}-\lambda_{1}}[\mathrm{OH}]_{\mathrm{T}}}
\end{aligned}
$$

where $\lambda_{1}$ and $\lambda_{2}$ are given by

$$
\begin{aligned}
\lambda_{1,2}= & 1 / 2\left\{-\left(k_{\mathrm{e}}[\mathrm{OH}]_{\mathrm{T}}+k_{\mathrm{i}}[\mathrm{M}]+k_{\mathrm{e}}[\mathrm{Cat}]_{\mathrm{T}}\right) \pm\right. \\
& {\left.\left[\left(k_{\mathrm{e}}[\mathrm{OH}]_{\mathrm{T}}+k_{\mathrm{i}}[\mathrm{M}]+k_{\mathrm{e}}[\mathrm{Cat}]_{\mathrm{T}}\right)^{2}-4 k_{\mathrm{i}}[\mathrm{M}] k_{\mathrm{e}}[\mathrm{Cat}]_{\mathrm{T}}\right]^{1 / 2}\right\} }
\end{aligned}
$$

1.2 The Monomer Conversion. In immortal ROP the enchained monomers M are distributed over OH-terminated (major) and C-terminated (minor) molecules. The conversion, i.e. the concentration of bound monomer $[\mathrm{M}]_{\mathrm{B}}$, is given by:

$$
\begin{aligned}
{[\mathrm{M}]_{\mathrm{B}}=} & k_{\mathrm{p}}[\mathrm{M}][\mathrm{Cat}]_{\mathrm{T}} t+\left(k_{\mathrm{i}}-k_{\mathrm{p}}\right) k_{\mathrm{e}}^{-1}[\mathrm{M}]\left(\lambda_{2}-\lambda_{1}\right)^{-1} \times \\
& \left\{\left(k_{\mathrm{e}}[\mathrm{Cat}]_{\mathrm{T}}+\lambda_{1}\right) \lambda_{1}^{-1} \lambda_{2}\left[-1+\mathrm{e}^{\lambda_{1} t}\right]-\left(k_{\mathrm{e}}[\mathrm{Cat}]_{\mathrm{T}}+\lambda_{2}\right) \lambda_{1} \lambda_{2}^{-1}\left[-1+\mathrm{e}^{\lambda_{2} t}\right]\right\}
\end{aligned}
$$

with $\lambda_{1,2}$ as defined in eq (3c). Eq (4) (cf. Supporting Information) describes the rate of monomer consumption as a function of time. Since for a given experiment $[\mathrm{Cat}]_{\mathrm{T}},[\mathrm{HO}]_{\mathrm{T}}$ and $[\mathrm{M}]$ are known experimental values, this equation can be fitted to experimental curves using the three rate constants $k_{\mathrm{e}}, k_{\mathrm{i}}$ and $k_{\mathrm{p}}$ which characterize all immortal ROP reactions. The initiation phase, whether under "immortal" or "living" conditions, is often overlooked in available kinetic analyzes of ROP reactions but can provide an explanation for the positive or negative curvature of the consumption profiles in the early stages of the reaction. 


\section{Tin-catalyzed immortal ring-opening polymerizations}

Tin(II) precatalysts are suited to the monitoring of ROP reactions by NMR techniques, ${ }^{11,12}$ because they offer a good compromise of activity, control over the polymerization parameters and robustness. ${ }^{16}$ The applicability of eq (4) was therefore tested using the tin(II) catalyst shown in Chart 1.

A range of polymerizations carried out in toluene- $d_{8}$ at $25-80{ }^{\circ} \mathrm{C}$ were monitored by ${ }^{1} \mathrm{H}$ NMR spectroscopy. The immortal ROP of L-LA mediated by the binary group 14 precatalysts 1-6 activated by a molar excess of $i \mathrm{PrOH}$ shows an initiation phase, as well as the effect of monomer depletion when conversion exceeds $60 \%$. The initiation phase is more evident when plotting the slope of the conversion curve as a function of conversion (Figure 1).
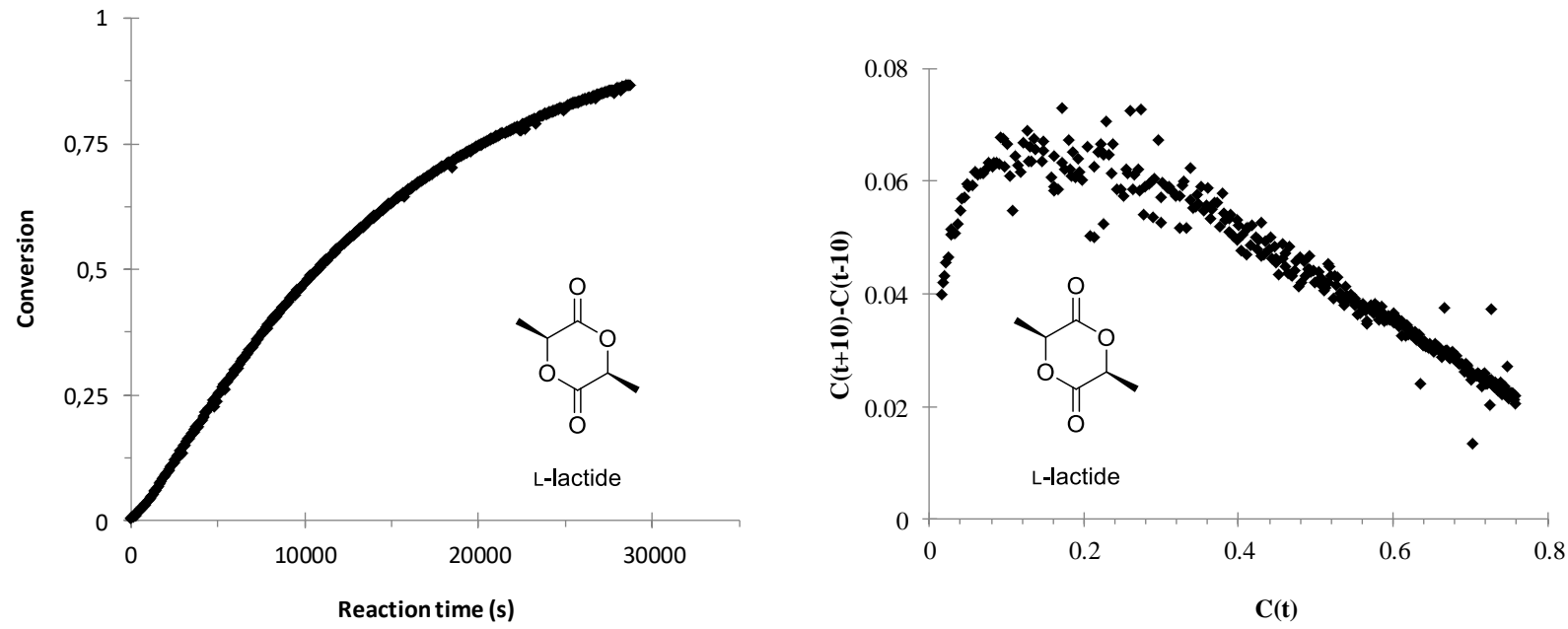

Figure 1. L-LA polymerization catalyzed by $1 / i \mathrm{PrOH}$ in toluene, $25{ }^{\circ} \mathrm{C} .[\mathrm{Sn}]_{\mathrm{T}}=5.0 \mathrm{mM},[\mathrm{L}-\mathrm{LA}]_{\mathrm{T}}=$ $0.33 \mathrm{M},[\mathrm{L}-\mathrm{LA}]_{\mathrm{T}} /[\mathrm{Sn}]_{\mathrm{T}} /[i \mathrm{PrOH}]_{\mathrm{T}}=66: 1: 5$. Left: Monomer conversion $v s$. reaction time. Right: Plot of the slope of conversion curve $v s$. conversion $\mathrm{C}(\mathrm{t})$, showing the initiation phase.

The immortal ROP of L-LA (100 equiv) at $60{ }^{\circ} \mathrm{C}$ catalyzed by a mixture of 1 with $10 i \mathrm{PrOH}$ $\left([\mathrm{L}-\mathrm{LA}]_{\mathrm{T}} /[\mathrm{Sn}]_{\mathrm{T}} /[i \mathrm{PrOH}]_{\mathrm{T}}=100: 1: 10 ;[\mathrm{L}-\mathrm{LA}]_{\mathrm{T}}=1.0 \mathrm{M}\right)$ constituted our benchmark experiment: typically for this and all related catalysts, the rate of monomer consumption follows first-order dependence upon monomer concentration. Eyring analysis of data for the ROP of L-LA in the temperature range $40-80{ }^{\circ} \mathrm{C}$ gave activation parameters $\left(\Delta \mathrm{H}^{\ddagger}=13.2 \mathrm{kcal} \cdot \mathrm{mol}^{-1}\right.$ and $\Delta \mathrm{S}^{\ddagger}=-32.8$ 
$\mathrm{cal} \cdot \mathrm{K}^{-1} \cdot \mathrm{mol}^{-1}$ ) comparable with those reported before for related systems; ${ }^{10}$ the largely negative value of $\Delta \mathrm{S}^{*}$ points at an associated transition state (cf. Supporting Information Figure $\mathrm{S} 1$ ).

Table 1 collects the observed rate constants $\left(k_{\mathrm{obs}}\right)$ for $\mathrm{Sn}(\mathrm{II})$ catalyzed polymerization reactions performed in toluene- $d_{8}$ with a large excess of alcohol as a chain transfer agent $(5-40$ equiv vs. Sn). The values of $k_{\mathrm{obs}}$ are comparable for polymerizations carried out with different precatalysts, all other conditions remaining identical: compare for instance entries 2 and 3, 4 and 5, 6 and 7 or 10 and 11 . Comparison of their respective $k_{\text {obs }}$ show that the bis(amido) precatalyst 5 induces slightly better activity than the heteroleptic amido catalyst precursor $\mathbf{1}$.

Non-linear regression was performed to assess the validity of eq (4), substituting $[\mathrm{Cat}]_{\mathrm{T}}$ by $[\mathrm{Sn}]_{\mathrm{T}}$ for the concentration of the total of tin species involved. The value of $k_{\mathrm{e}}$ for all curve-fitting experiments collected in Table 1 was set to $100 \mathrm{~L} \cdot \mathrm{mol}^{-1} \cdot \mathrm{s}^{-1} \cdot{ }^{17}$ The decision to constrain $k_{\mathrm{e}}$ to a high value (i.e. $k_{\mathrm{e}} \gg k_{\mathrm{i}}, k_{\mathrm{p}}$ ) is justified by the fact that well-controlled immortal ROP processes produce polymers with narrow molecular weight distributions (typically $M_{\mathrm{w}} / M_{\mathrm{n}}<1.10$ ), ${ }^{7,11,12}$ a fact which can only be accounted for by assuming that the rate of exchange between dormant and growing macromolecules is much greater than initiation and chain growth. ${ }^{18}$

The values of $k_{\mathrm{i}}$ and $k_{\mathrm{p}}$ determined using eq (4) for immortal ROP reactions fall characteristically in the range $0.50-5.00 \times 10^{-2} \mathrm{~L}_{\mathrm{mol}} \mathrm{mol}^{-1} \cdot \mathrm{s}^{-1}$, and are similar to those determined for regular living polymerizations catalyzed by the same tin(II) precatalysts under comparable conditions. ${ }^{12}$ Since these binary systems exhibit first order kinetics in [monomer] and a zero order dependence in $[i \mathrm{PrOH}]$ when sufficient excess of alcohol is used (ca. $5-7$ equiv $v s$. the metal, see below), the relationship $k_{\mathrm{obs}}=k_{\mathrm{p}} \times[\mathrm{Sn}]_{\mathrm{T}}$ is verified to an excellent level of accuracy (Table 1$)$. 
Table 1. Kinetic parameters for the immortal ROP of L-LA and TMC catalyzed by tin(II)/iPrOH binary catalysts. ${ }^{a}$

\begin{tabular}{|c|c|c|c|c|c|c|c|c|c|c|c|}
\hline Entry & $\mathrm{Sn}$ & $\mathrm{M}$ & $\begin{array}{c}\mathrm{T} \\
\left({ }^{\circ} \mathrm{C}\right)\end{array}$ & {$[\mathrm{M}] /[\mathrm{Sn}]_{\mathrm{T}} /[i \mathrm{PrOH}]_{\mathrm{T}}$} & $\begin{array}{l}{[\mathrm{M}]} \\
(\mathrm{M})\end{array}$ & $\begin{array}{l}{[\mathrm{Sn}]_{\mathrm{T}}} \\
(\mathrm{mM})\end{array}$ & $\begin{array}{l}i \mathrm{PrOH}]_{\mathrm{T}} \\
(\mathrm{mM})\end{array}$ & $\begin{array}{c}k_{\mathrm{obs}} \times 10^{4 b} \\
\left(\mathrm{~s}^{-1}\right)\end{array}$ & $\begin{array}{c}k_{\mathrm{p}} \times 10^{2 c} \\
\left(\mathrm{~L} \cdot \mathrm{mol}^{-1} \cdot \mathrm{s}^{-1}\right)\end{array}$ & $\begin{array}{c}k_{\mathrm{i}} \times 10^{2 c} \\
\left(\mathrm{~L} \cdot \mathrm{mol}^{-1} \cdot \mathrm{s}^{-1}\right)\end{array}$ & $\begin{array}{c}k_{\mathrm{p}} \times 10^{2 d} \\
\left(\mathrm{~L} \cdot \mathrm{mol}^{-1} \cdot \mathrm{s}^{-1}\right)\end{array}$ \\
\hline 1 & 1 & L-LA & 25 & $66: 1: 5$ & 0.33 & 5.00 & 25.0 & 0.72 & $1.54 \pm 0.04$ & $0.62 \pm 0.01$ & $1.34 \pm 0.002$ \\
\hline 3 & 5 & L-LA & 25 & $66: 1: 10$ & 0.33 & 5.00 & 50.0 & 1.06 & $1.78 \pm 0.02$ & $1.81 \pm 0.01$ & $2.14 \pm 0.001$ \\
\hline 4 & 1 & L-LA & 45 & 100:1:10 & 0.50 & 5.00 & 50.0 & 4.72 & $6.68 \pm 0.05$ & $7.36 \pm 0.08$ & $8.98 \pm 0.03$ \\
\hline 7 & 5 & L-LA & 45 & $200: 1: 20$ & 0.50 & 2.50 & 50.0 & 4.34 & $12.77 \pm 0.12$ & $16.51 \pm 0.25$ & $17.20 \pm 0.01$ \\
\hline 8 & 1 & L-LA & 60 & $100: 1: 10$ & 0.50 & 5.00 & 50.0 & 12.46 & $18.94 \pm 0.20$ & $19.50 \pm 0.40$ & $25.86 \pm 0.05$ \\
\hline 9 & 5 & L-LA & 60 & 100:1:10 & 0.50 & 5.00 & 50.0 & 19.13 & $25.44 \pm 0.24$ & $34.49 \pm 0.86$ & $37.51 \pm 0.20$ \\
\hline 10 & 1 & L-LA & 60 & 200:1:20 & 0.50 & 2.50 & 50.0 & 8.30 & $25.77 \pm 0.25$ & $25.86 \pm 0.43$ & $33.36 \pm 0.05$ \\
\hline 14 & 1 & TMC & 60 & $100: 1: 10$ & 1.00 & 10.0 & 100 & 2.78 & $3.05 \pm 0.06$ & $1.70 \pm 0.04$ & $2.95 \pm 0.01$ \\
\hline 15 & 1 & TMC & 60 & 100:1:16 & 1.00 & 10.0 & 160 & 2.37 & $2.65 \pm 0.07$ & $1.49 \pm 0.03$ & $2.60 \pm 0.01$ \\
\hline 16 & 1 & TMC & 60 & $166: 1: 16$ & 1.00 & 6.00 & 100 & 1.88 & $3.35 \pm 0.09$ & $1.43 \pm 0.04$ & $3.00 \pm 0.005$ \\
\hline
\end{tabular}

${ }^{a}$ Polymerizations in toluene- $d_{8}$; see experimental section for details. ${ }^{b}$ Observed rate constant determined from the semi-logarithmic plot of monomer conversion $v s$. time. ${ }^{c}$ Determined by curve-fitting using eq (4), and arbitrarily setting the value of $k_{\mathrm{e}}$ to $100 \mathrm{~L} \cdot \mathrm{mol}^{-1} \cdot \mathrm{s}^{-1}$ for all entries. ${ }^{d}$ Determined from eq (5) corresponding to the monomer depletion phase. 
The validity of our analysis was further supported by comparing values of $k_{\mathrm{p}}$ determined using eq (4) and those obtained by conventional methods for the controlled polymerization of L-LA promoted 2 without added alcohol (i.e. under living conditions; see below for the role of excess alcohol in immortal polymerizations catalyzed by $\mathbf{1}-\mathbf{5} / i \mathrm{PrOH})$. The linear plot of $k_{\mathrm{obs}} v s$. [Sn] indicates first order dependence in precatalyst concentration (cf Supporting Information, Figure S2), and the propagation rate constant obtained as the slope $\left(k_{\mathrm{p}}=4.84 \pm 0.01 \times 10^{-2} \mathrm{~L} \cdot \mathrm{mol}^{-1} \cdot \mathrm{s}^{-1}\right)$ was commensurate with those determined by fitting the same data sets to eq (4) with $[i \operatorname{PrOH}]_{0}=0$ $\mathrm{mol} \cdot \mathrm{L}^{-1}$ (in the range $4.09 \pm 0.06-4.83 \pm 0.01 \times 10^{-2} \mathrm{~L} \cdot \mathrm{mol}^{-1} \cdot \mathrm{s}^{-1}$ ). ${ }^{19}$ Conventional analysis (i.e. plots of $\left.\ln \left(k_{\mathrm{obs}}\right) v s \cdot \ln \left([\mathrm{Sn}]_{\mathrm{T}}\right)\right)$ affords of course a single value of $k_{\mathrm{p}}$, with no access to $k_{\mathrm{i}}$, for a complete set of experiments where $[\mathrm{Sn}]_{\mathrm{T}}$ is changed, while curve-fitting each of these experiments to the kinetic model affords its own value of $k_{\mathrm{p}}$.

Cases where an initiation period is observed are characterized by $k_{\mathrm{i}}<k_{\mathrm{p}}$ (entries $1-2$ and 14 - 16). In the present tin system the two rate constants remain roughly of the same order of magnitude. As expected from the kinetic mechanism, there is no impact on the molecular weight distributions of the polymers that are produced with these tin(II) catalyts: independent of the reactions conditions, $M_{\mathrm{w}} / M_{\mathrm{n}}<1.11$ is systematically found at partial monomer conversion (cf. SI Table S2).

An example of immortal ROP of L-LA catalyzed by the $1 / i \mathrm{PrOH}$ binary catalyst submitted to curve-fitting with eq (4) is presented in Figure 2. The curve fitting for enchained monomer $[\mathrm{M}]_{\mathrm{B}}$ as function of reaction time depicted shows that at $25{ }^{\circ} \mathrm{C}$, initiation of the polymerization of $\mathrm{M}=\mathrm{L}-$ LA catalyzed by $\mathbf{1}+5 i \mathrm{PrOH}$ is slower than propagation, $k_{\mathrm{i}}=0.62 \pm 0.01 \times 10^{-2}$ and $k_{\mathrm{p}}=1.54 \pm$ $0.04 \times 10^{-2} \mathrm{~L} \cdot \mathrm{mol}^{-1} \cdot \mathrm{s}^{-1}$; the curve shape is typical of such scenarios. 


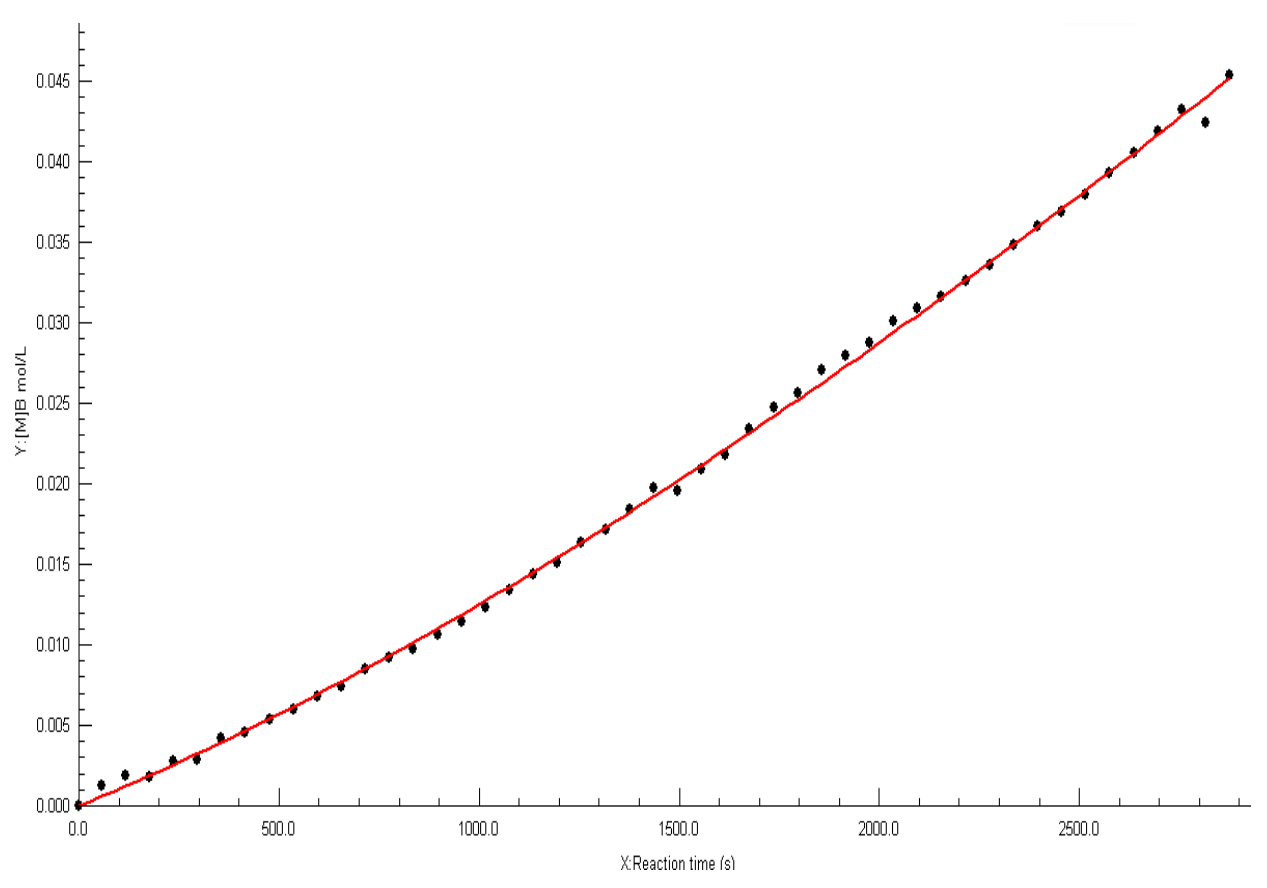

Figure 2. Curve fitting for enchained monomer $[\mathrm{L}-\mathrm{LA}]_{\mathrm{B}} v s$. time $\left([\mathrm{L}-\mathrm{LA}]_{\mathrm{B} \text {, maximum }}=0.33 \mathrm{M}\right)$ for the immortal ROP of L-LA catalyzed by the $\mathrm{Sn}(\mathrm{II})$ amide precatalyst 1 and $i \mathrm{PrOH}$. Reaction conditions: solvent $=$ toluene- $d_{8}, 25^{\circ} \mathrm{C},[\mathrm{L}-\mathrm{LA}]_{\mathrm{T}} /[\mathrm{Sn}]_{\mathrm{T}} /[i \mathrm{PrOH}]_{\mathrm{T}}=66: 1: 5,[\mathrm{Sn}]_{\mathrm{T}}=5.0 \mathrm{mM},[\mathrm{L}-\mathrm{LA}]_{\mathrm{T}}=0.33 \mathrm{M}$. Fitted curve: plain line; experimental data: black dots; $k_{\mathrm{i}}=0.62 \pm 0.01 \times 10^{-2} \mathrm{~L}^{\mathrm{mol}} \mathrm{m}^{-1} \cdot \mathrm{s}^{-1}, k_{\mathrm{p}}=1.54$ $\pm 0.04 \times 10^{-2} \mathrm{~L} \cdot \mathrm{mol}^{-1} \cdot \mathrm{s}^{-1} ; R^{2}>0.999$.

For representative curve-fitting plots of $[\mathrm{M}]_{\mathrm{B}} v s$. time for other experiments in Table 1 see Supporting Information (Figures S3 - S8). In all cases, the agreement between the theoretical curves established from eq $(4)$ and the experimental data was excellent $\left(R^{2} \approx 0.999\right)$. Examples where the initiation is faster than propagation were obtained for more reactive systems and/or higher temperature. ${ }^{20}$ The polymerization of L-LA catalyzed by the homoleptic $\mathbf{5}+10 i \operatorname{PrOH}$ at 45 ${ }^{\circ} \mathrm{C}$ (Table 1, entry 5; SI Figure S9) and that catalyzed by the tin(II) lactate $2+i \mathrm{PrOH}$ at $60{ }^{\circ} \mathrm{C}$ with high loadings of monomer and chain transfer agent (Table 1, entry 12; SI Figure S10) are representative examples.

Trimethylenecarbonate. TMC shows similar behavior, but with a more pronounced initiation phase (Figure 3). The immortal ROP of TMC mediated by $\mathbf{1} / \mathrm{iPrOH}$ is slower than that of L-LA (Table 1). Initial data showed that this reaction proceeds with slow initiation; this was confirmed by curvefitting (SI Figure S11): $k_{\mathrm{i}}=1.70 \pm 0.04 \times 10^{-2}$ and $k_{\mathrm{p}}=3.05 \pm 0.06 \times 10^{-2} \mathrm{~L} \cdot \mathrm{mol}^{-1} \cdot \mathrm{s}^{-1}$. 

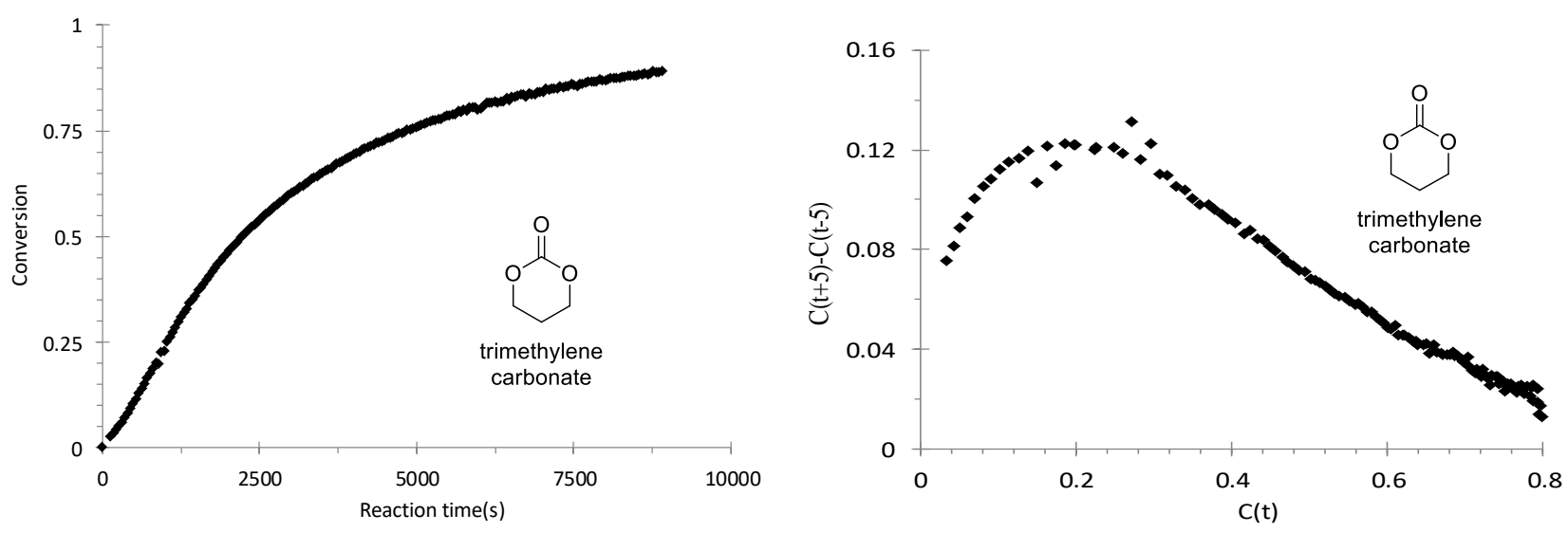

Figure 3. TMC polymerization catalyzed by $1 / i \operatorname{PrOH}$ in toluene, $60{ }^{\circ} \mathrm{C}$. $[\mathrm{Sn}]_{\mathrm{T}}=10.0 \mathrm{mM},[\mathrm{TMC}]_{\mathrm{T}}$ $=1.0 \mathrm{M},[\mathrm{TMC}]_{\mathrm{T}} /[\mathrm{Sn}]_{\mathrm{T}} /[i \operatorname{PrOH}]_{\mathrm{T}}=100: 1: 10$. Left: Monomer conversion vs. reaction time. Right: Plot of the slope of conversion curve vs. conversion, showing the initiation phase.

Germanium catalysts. The germanium(II) complex $\left\{\mathrm{LO}^{3}\right\} \mathrm{Ge}\left(\mathrm{N}\left(\mathrm{SiMe}_{3}\right)_{2}\right)(\mathbf{6})$ has been shown to promote the ROP of L-LA. ${ }^{10 \mathrm{~g}}$ The polymerization of L-LA (200 equiv) with this catalyst in the presence of 20 equiv of $i \mathrm{PrOH}\left([\mathrm{L}-\mathrm{LA}]_{\mathrm{T}}=1.00 \mathrm{M}, T=70^{\circ} \mathrm{C}\right)$ allowed us to record a larger number of data points for conversions below $10 \%$, and curve-fitting $\left(R^{2}=0.999\right)$ demonstrated that propagation was faster than initiation (Figure S12; $k_{\mathrm{i}}=29.0 \pm 0.28 \times 10^{-4} \mathrm{~L} \cdot \mathrm{mol}^{-1} \cdot \mathrm{s}^{-1}, k_{\mathrm{p}}=58.0 \pm$ $\left.0.83 \times 10^{-4} \mathrm{~L} \cdot \mathrm{mol}^{-1} \cdot \mathrm{s}^{-1}\right)$.

\section{Monomer depletion}

During ROP reactions, the concentration of monomer decays with first-order dependence on monomer and catalyst concentration, that is

$[\mathrm{M}]_{\mathrm{t}}=[\mathrm{M}]_{0} \mathrm{e}^{-k_{\mathrm{p}}[\mathrm{Cat}]_{\mathrm{T}} t}$

Since the concentration in bound monomer is $[M]_{B}=[M]_{0}-[M]_{t}$, the later phase of the polymerization can be fitted to eq (5):

$[\mathrm{M}]_{\mathrm{B}}=[\mathrm{M}]_{0}\left(1-\mathrm{e}^{-k_{\mathrm{p}}[\mathrm{Cat}]_{\mathrm{T}} t}\right)$ 
The values of $k_{\mathrm{p}}$ determined using data points for conversion above $50 \%$ are in the range $1.12 \times$ $10^{-2}$ to $48.00 \times 10^{-2} \mathrm{~L} \cdot \mathrm{mol}^{-1} \cdot \mathrm{s}^{-1}$. These values are in excellent agreement with those estimated independently for the initial stage of the reaction using eq (4), which provides good confirmation of the validity of the non-linear model.

The monomer equilibrium concentration $\left(0.014 M\right.$ at $25{ }^{\circ} \mathrm{C}, 0.024 M$ at $45{ }^{\circ} \mathrm{C}$ and $0.036 \mathrm{M}$ at $\left.60{ }^{\circ} \mathrm{C}\right)^{9 \mathrm{a}}$ could be significant in our experiments carried out at relatively low monomer concentrations: $[\mathrm{LA}]_{\mathrm{T}}=0.33 \mathrm{M}$ at $25{ }^{\circ} \mathrm{C}, 0.5 \mathrm{M}$ at $45{ }^{\circ} \mathrm{C}$ and $0.5 \mathrm{M}$ at $60{ }^{\circ} \mathrm{C}$, where the maximum conversions are therefore 95.8, 95.1 and 92.9\%. The resulting asymptote at high conversion can be corrected by substituting $[\mathrm{M}]_{\mathrm{B}}$ by $[\mathrm{M}]_{\mathrm{B}}-[\mathrm{M}]_{\mathrm{eq}}$ as reported by Duchateau and co-workers, ${ }^{21}$ but we found that this had negligible effect on the calculated values of $k_{\mathrm{p}}$.

\section{Dependence of rate on $[\mathrm{ROH}]$ for tin(II)-mediated immortal ROP catalysis}

In general, the rates of immortal lactide ring-opening polymerizations under steady-state conditions do not depend on $[\mathrm{ROH}]_{\mathrm{T}}$. However, with the present tin(II) systems, an increase in rate with increasing $[\mathrm{ROH}]_{\mathrm{T}}$ is observed for $[\mathrm{ROH}]_{\mathrm{T}} /[\mathrm{Sn}]_{\mathrm{T}}$ molar ratios in the range of $1: 1-5: 1$. Figure 4 shows the effect of $[\mathrm{ROH}]_{\mathrm{T}}$, expressed as $[\text { polymer chains }]_{\mathrm{T}} /[\mathrm{Sn}]_{\mathrm{T}}$ for constant $[\mathrm{Sn}]_{\mathrm{T}}=10.0 \mathrm{mM}$, on the observed rate constant $k_{\mathrm{obs}}$ in the immortal ROP of L-LA catalyzed by $\mathbf{1}$ or $\mathbf{2}$ combined with $i \operatorname{PrOH}$. 


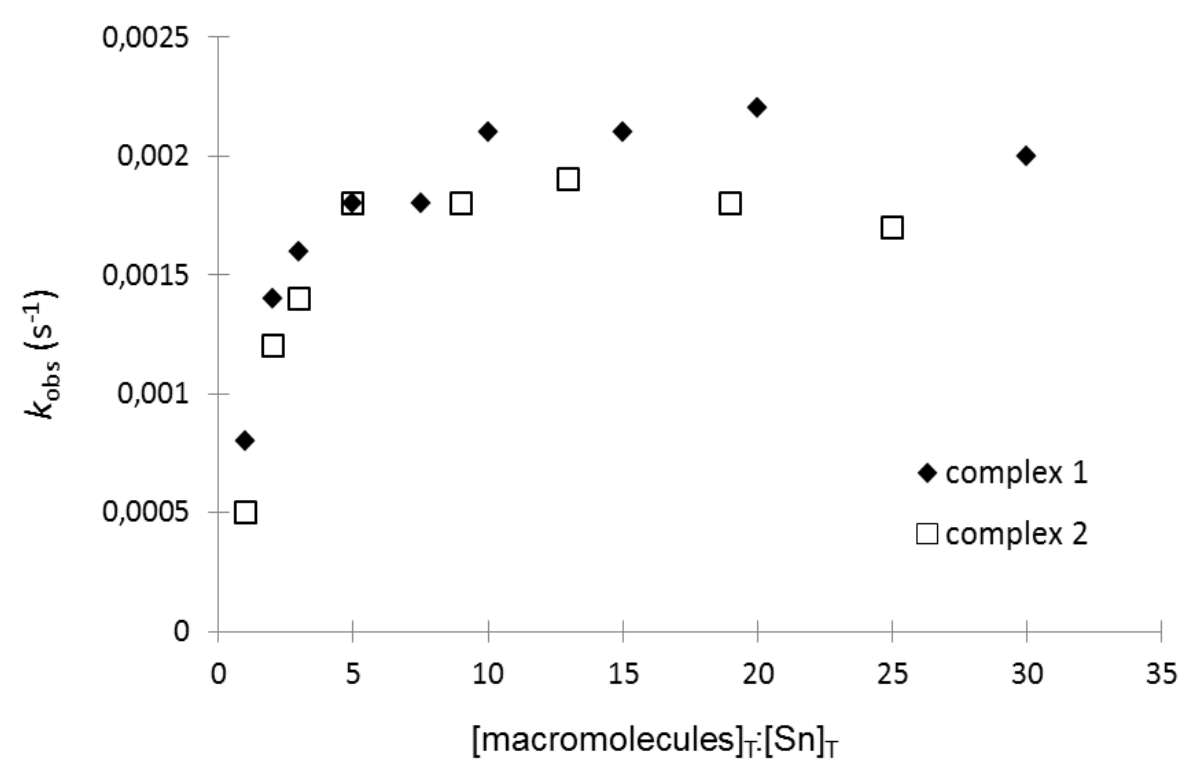

Figure 4. Dependence of the observed rate $k_{\mathrm{obs}}$ of L-LA polymerization catalyzed by the tin heteroleptic precatalysts $\mathbf{1}(\bullet)$ or $\mathbf{2}(\square)$ on $\left.[i \mathrm{PrOH}]_{\mathrm{T}}(\text { expressed as [polymer chains }]_{\mathrm{T}} /[\mathrm{Sn}]_{\mathrm{T}}\right)$ in toluene- $d_{8}$ at $60{ }^{\circ} \mathrm{C}$ with $[\mathrm{L}-\mathrm{LA}]_{\mathrm{T}}=1.0 \mathrm{M},[\mathrm{Sn}]_{\mathrm{T}}=10.0 \mathrm{mM}$.

The lactato catalyst $\mathbf{2}$ is capable of polymerizing L-LA even without addition of $i \mathrm{PrOH}$ via insertion of the monomer in the $\mathrm{Sn}-\mathrm{O}_{\text {lactate }}$ bond, ${ }^{11 \mathrm{~b}}$ hence the total number of polymer chains generated per metal centre is equal to $1+[i \mathrm{PrOH}]_{\mathrm{T}} /[\mathrm{Snn}]_{\mathrm{T}}{ }^{22}$

Significantly, the homoleptic tin bis(alkoxide) $3(n=2)$ shows different kinetic behavior (cf. SI Table S3). The addition of $0-24$ equiv of $i \mathrm{PrOH}$ has no effect on the rate of reaction; within experimental error, the rates of polymerization with $\mathrm{Sn}(\mathrm{O} i \mathrm{Pr})_{2}$ and $\left\{\mathrm{LO}^{i}\right\} \mathrm{Sn}(\mathrm{O} i \mathrm{Pr})+i \mathrm{PrOH}(4$ equiv or more) are near-identical (and not retarded by added $\left.\mathrm{HN}\left(\mathrm{SiMe}_{3}\right)_{2}\right)$.

These kinetic data, together with the similarity of the propagation rates $k_{\mathrm{p}}$ determined using the kinetic model for the immortal ROP of L-LA with $\mathbf{1}$ or $\mathbf{5}$ in the presence of excess alcohol (Table 1), suggest that the increase in rate with increasing alcohol content observed for amido catalyst precursors is related to the generation of alkoxide species. The formation of $\left\{\mathrm{LO}^{i}\right\} \operatorname{Sn}(\mathrm{O} i \operatorname{Pr})$ by reaction of $\left\{\mathrm{LO}^{i}\right\} \mathrm{Sn}\left(\mathrm{N}\left(\mathrm{SiMe}_{3}\right)_{2}\right)$ with $i \mathrm{PrOH}$ is quantitative and irreversible, as demonstrated by NMR spectroscopy. ${ }^{23}$ Moreover, we have shown previously that excess alcohol is able to reversibly release the phenol ligand from heteroleptic phenolate tin(II) alkoxide complexes. ${ }^{11 \mathrm{a}}$ Hence, further experiments were carried out to assess whether the increase in reaction rate with increasing [ROH] 
is the result of the slow conversion of the poorly active tin amide precursor into the much more active alkoxide species $\left\{\mathrm{LO}^{i}\right\} \mathrm{Sn}(\mathrm{O} i \mathrm{Pr})$ and/or $\mathrm{Sn}(\mathrm{O} i \mathrm{Pr})_{2}$ (Scheme 2). In this case, after formation of the isopropoxide(s), one would expect the reaction rate to be identical to that of the living polymerization, or that measured starting with pre-made $\left\{\mathrm{LO}^{i}\right\} \operatorname{Sn}(\mathrm{O} i \mathrm{Pr})$.

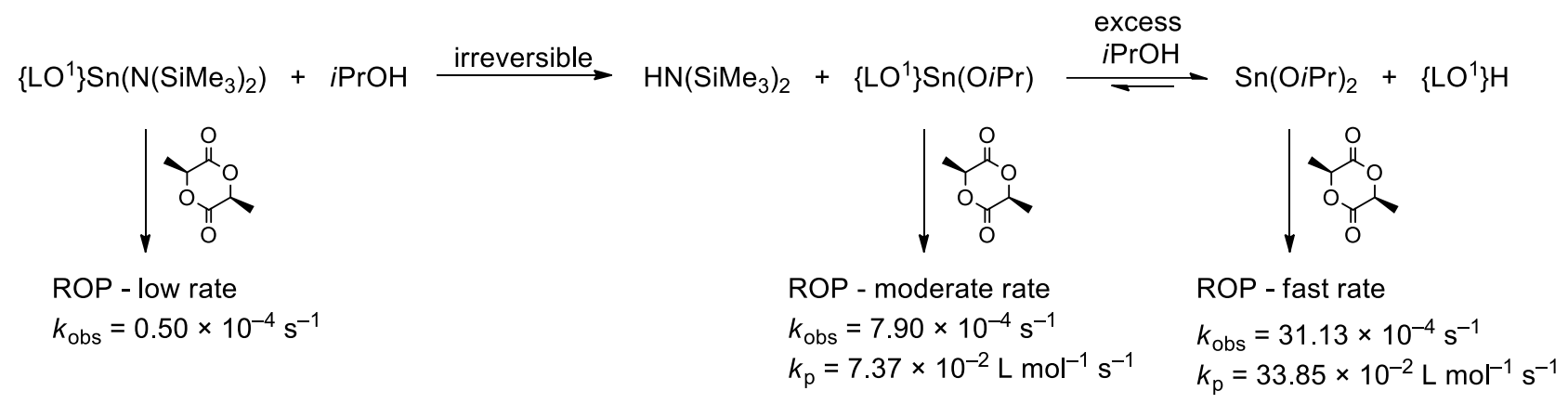

\section{Scheme 2}

Without added alcohol, the amido complexes 1, 4 and 5 constitute sluggish ROP initiators, and do not afford controlled reactions. ${ }^{24}$ For example, the batch-scale ROP of L-LA initiated by 5 in toluene took $4 \mathrm{~h}$ at $60{ }^{\circ} \mathrm{C}$ to yield near quantitatively a material of uncontrolled molecular weight $\left([\mathrm{L}-\mathrm{LA}]_{\mathrm{T}} /[\mathrm{Sn}]_{\mathrm{T}}=25: 1,[\mathrm{~L}-\mathrm{LA}]_{\mathrm{T}}=0.75 \mathrm{M}, M_{\mathrm{n}, \text { theo }}=3,300 \mathrm{~g} \cdot \mathrm{mol}^{-1}, M_{\mathrm{n}, \mathrm{SEC}}=59,600 \mathrm{~g} \cdot \mathrm{mol}^{-1}, M_{\mathrm{w}} / M_{\mathrm{n}}\right.$ $=1.32)$.

Table 2 summarises the influence of $i \mathrm{PrOH}$ concentration in the polymerization of L-LA catalyzed by 1-5 during NMR-scale reactions. Whereas the reaction catalyzed by $\mathbf{1}$ is slow in the absence of added alcohol (line 1), at the same temperature the reaction is faster and the molecular weight is controlled ${ }^{12}$ if one equiv of $i \mathrm{PrOH}$ is added to the system (line 2). By contrast, the lactato complex 2 and the bis(isopropoxide) 3 both catalyze ROP of L-LA without alcohol (line 1). Rates increase in the sequence $1<\mathbf{2}<\mathbf{3}$. The addition of $2-10$ equiv of $\mathrm{HN}\left(\mathrm{SiMe}_{3}\right)_{2}$ to $\mathbf{3}$ do not alter the rate of the polymerization catalyzed by tin bis(isopropoxide) (Table 2 lines 1,5 and 12). Remarkably, the addition of 1 equiv of $i \mathrm{PrOH}$ or methyl $(S, S)$-lactidate to either $\mathbf{1}$ or $\mathbf{4}$ provides catalysts that essentially behave in the same fashion as $\mathbf{2}$ by itself (Table 2). 
Table 2. Influence of $i \mathrm{PrOH}$ concentration in the polymerization of L-lactide catalyzed by $\mathbf{1 - 5} .^{a}$

\begin{tabular}{|c|c|c|c|c|c|c|c|c|c|c|c|}
\hline & \multirow{2}{*}[\mathrm{L}-\mathrm{LA}]{$_{\mathrm{T}} /[\mathrm{Sn}]_{\mathrm{T}} /[\mathrm{ROH}]_{\mathrm{T}}$} & \multicolumn{2}{|c|}{$\begin{array}{c}\left\{\mathrm{LO}^{1}\right\} \mathrm{Sn}\left(\mathrm{N}\left(\mathrm{SiMe}_{3}\right)_{2}\right) \\
(\mathbf{1})\end{array}$} & \multicolumn{2}{|c|}{$\begin{array}{c}\left\{\mathrm{LO}^{2}\right\} \mathrm{Sn}(t \mathrm{Bu}(R) \text {-lactate }) \\
(2)\end{array}$} & \multicolumn{2}{|c|}{$\begin{array}{c}{\left[\mathrm{Sn}(\mathrm{O} i \mathrm{Pr})_{2}\right]_{2}} \\
(\mathbf{3}) \\
\end{array}$} & \multicolumn{2}{|c|}{$\begin{array}{c}\left\{\mathrm{LO}^{4}\right\} \mathrm{Sn}\left(\mathrm{N}\left(\mathrm{SiMe}_{3}\right)_{2}\right) \\
(4)\end{array}$} & \multicolumn{2}{|c|}{$\begin{array}{c}\mathrm{Sn}\left(\mathrm{N}\left(\mathrm{SiMe}_{3}\right)_{2}\right)_{2} \\
(\mathbf{5})\end{array}$} \\
\hline & & $\begin{array}{c}k_{\mathrm{obs}} \times 10^{4} \\
\left(\mathrm{~s}^{-1}\right)\end{array}$ & $\begin{array}{c}k_{\mathrm{p}} \times 10^{2 b} \\
\left(\mathrm{~L} \cdot \mathrm{mol}^{-1} \cdot \mathrm{s}^{-1}\right)\end{array}$ & $\begin{array}{c}k_{\mathrm{obs}} \times 10^{4} \\
\left(\mathrm{~s}^{-1}\right)\end{array}$ & $\begin{array}{c}k_{\mathrm{p}} \times 10^{2 b} \\
\left(\mathrm{~L} \cdot \mathrm{mol}^{-1} \cdot \mathrm{s}^{-1}\right)\end{array}$ & $\begin{array}{c}k_{\mathrm{obs}} \times 10^{4} \\
\left(\mathrm{~s}^{-1}\right)\end{array}$ & $\begin{array}{c}k_{\mathrm{p}} \times 10^{2} b \\
\left(\mathrm{~L} \cdot \mathrm{mol}^{-1} \cdot \mathrm{s}^{-1}\right)\end{array}$ & $\begin{array}{c}k_{\mathrm{obs}} \times 10^{4} \\
\left(\mathrm{~s}^{-1}\right)\end{array}$ & $\begin{array}{c}k_{\mathrm{p}} \times 10^{2 b} \\
\left(\mathrm{~L} \cdot \mathrm{mol}^{-1} \cdot \mathrm{s}^{-1}\right)\end{array}$ & $\begin{array}{c}k_{\mathrm{obs}} \times 10^{4} \\
\left(\mathrm{~s}^{-1}\right)\end{array}$ & $\begin{array}{c}k_{\mathrm{p}} \times 10^{2 b} \\
\left(\mathrm{~L} \cdot \mathrm{mol}^{-1} \cdot \mathrm{s}^{-1}\right)\end{array}$ \\
\hline 1 & 100:1:0 & 0.50 & $n / a^{c}$ & 5.35 & $5.15 \pm 0.01$ & 31.13 & $33.85 \pm 0.04$ & & & 2.97 & $n / a^{c}$ \\
\hline 2 & 100:1:1 & 7.90 & $7.37 \pm 0.02$ & 12.37 & $12.40 \pm 0.01$ & & & 3.57 & $3.50 \pm 0.01$ & 14.79 & $16.77 \pm 0.06$ \\
\hline 3 & & $5.47^{d}$ & $5.22 \pm 0.02^{d}$ & & & & & & & & \\
\hline 4 & $100: 1: 2$ & 14.05 & $13.83 \pm 0.05$ & 13.71 & $13.52 \pm 0.02$ & 27.79 & $32.23 \pm 0.16$ & 15.57 & $15.69 \pm 0.01$ & 14.51 & $15.39 \pm 0.04$ \\
\hline 5 & & & & & & $26.62^{e}$ & $29.00 \pm 0.10^{e}$ & & & & \\
\hline 6 & $100: 1: 3$ & 16.05 & $15.40 \pm 0.09$ & & & & & 16.51 & $17.31 \pm 0.04$ & & \\
\hline 7 & $100: 1: 4$ & & & 18.11 & $17.49 \pm 0.06$ & 26.44 & $28.81 \pm 0.10$ & & & & \\
\hline 8 & $100: 1: 5$ & 18.25 & $18.54 \pm 0.05$ & & & & & 19.25 & $19.97 \pm 0.02$ & & \\
\hline 9 & $100: 1: 7.5$ & 23.28 & $22.17 \pm 0.09$ & & & & & & & & \\
\hline 10 & $100: 1: 8$ & & & 18.44 & $18.87 \pm 0.04$ & 22.77 & $25.80 \pm 0.16$ & & & & \\
\hline 11 & 100:1:10 & 21.06 & $21.66 \pm 0.05$ & & & & & & & 18.62 & $17.49 \pm 0.05$ \\
\hline 12 & & & & & & $29.53^{e}$ & $27.50 \pm 0.20^{e}$ & & & & \\
\hline 13 & $100: 1: 12$ & & & 19.74 & $21.60 \pm 0.16$ & & & & & & \\
\hline 14 & 100:1:15 & 22.09 & $22.31 \pm 0.08$ & & & & & & & & \\
\hline 15 & 100:1:16 & & & & & 22.59 & $24.27 \pm 0.09$ & & & & \\
\hline 16 & 100:1:18 & & & 18.46 & $17.94 \pm 0.03$ & & & & & & \\
\hline 17 & $100: 1: 20$ & 21.51 & $20.27 \pm 0.10$ & & & & & & & & \\
\hline 18 & $100: 1: 24$ & & & 17.41 & $17.38 \pm 0.04$ & 21.44 & $22.50 \pm 0.11$ & & & & \\
\hline 19 & 100:1:30 & 20.19 & $18.41 \pm 0.13$ & & & & & & & & \\
\hline
\end{tabular}

${ }^{a}$ Polymerization conditions: toluene- $d_{8}$, alcohol $=i$ PrOH unless otherwise specified, $[\mathrm{L}-\mathrm{LA}]_{\mathrm{T}}=1.0 \mathrm{M},[\mathrm{Sn}]_{\mathrm{T}}=10 \mathrm{mM}$, and $T=60{ }^{\circ} \mathrm{C} .{ }^{b}$ Determined from eq (5). ${ }^{c}$ Data not suited to treatment with eq (5). ${ }^{d}$ Exogenous transfer agent $=$ methyl $(S, S)$-lactidate. ${ }^{e}$ Exogenous transfer agent $=\mathrm{HN}(\mathrm{SiMe} 3)_{2}$. 
Addition of more than 1 equiv of alcohol to $\mathbf{1 - 5}$ provides useful information. Instead of matching the catalytic activity observed for pre-formed bis(isopropoxide) $\mathbf{3}$, the reactivity of the $\mathrm{Sn}(\mathrm{II})$ bis(amide) 5 does not change if two equiv of $i \mathrm{PrOH}$ are used instead of one. This suggests that, contrary to expectations, the in situ reaction $5+2 i \mathrm{PrOH}$ does not generate tin bis(isopropoxide) but instead affords an intermediate species assumed to be $\mathrm{Sn}(\mathrm{O} i \mathrm{Pr})\left(\mathrm{N}\left(\mathrm{SiMe}_{3}\right)_{2}\right)$ (as further evidenced by ${ }^{119} \mathrm{Sn}$ NMR spectroscopy; vide infra). This mixed-ligand complex can be independently prepared by mixing 3 and 5 to give crystalline $\left[\operatorname{Sn}(\mu-\mathrm{O} i \operatorname{Pr})\left\{\mathrm{N}\left(\mathrm{SiMe}_{3}\right)_{2}\right\}\right]_{2}(\mathbf{7}) .{ }^{1} \mathrm{H}$ DOSY NMR diffusion measurements showed that it remains dimeric in aromatic solution. The synthesis, crystal structure and spectroscopic data of $\mathbf{7}$ are given in the Supporting Information.

The complex engages in reversible equilibria leading to the formation of small amounts ( $\mathrm{ca}$. $3 \%$ at $25^{\circ} \mathrm{C}, 9 \%$ at $\left.60{ }^{\circ} \mathrm{C}\right)$ of $\left[\mathrm{Sn}(\mathrm{OiPr})_{2}\right]_{2}$ and $\mathrm{Sn}\left(\mathrm{N}\left(\mathrm{SiMe}_{3}\right)_{2}\right)_{2}$. Increasing the temperature shifts the equilibrium towards homoleptic complexes; these changes are reversible on cooling to $25^{\circ} \mathrm{C}$. The ${ }^{119} \mathrm{Sn}\left\{{ }^{1} \mathrm{H}\right\}$ NMR spectrum of isolated 7 exhibits a single triplet centred on $\delta_{119 \mathrm{Sn}}=+42.1 \mathrm{ppm}$ $\left({ }^{1} J_{119 \mathrm{Sn}-14 \mathrm{~N}}=263 \mathrm{~Hz}\right)$. The product formed in situ by reaction of $\mathrm{Sn}\left(\mathrm{N}(\mathrm{SiMe})_{2}\right)_{2}(5)$ and 1 equiv of $i \mathrm{PrOH}$ in concentrations similar to those used for ROP reactions also featured the same resonance at $\delta_{119 \mathrm{Sn}}=+42.0 \mathrm{ppm}$. On the other hand, three multiplets at $\delta_{119 \mathrm{Sn}}=+91.8,+35.4$ and $+4.0 \mathrm{ppm}$ were detected in the ${ }^{119} \mathrm{Sn}\left\{{ }^{1} \mathrm{H}\right\}$ NMR spectrum of the reaction between $\mathbf{5}$ and $2 \mathrm{iPrOH}$. A spectrum also showing these resonances together with an additional one at $\delta_{119 \mathrm{Sn}}=+42.1 \mathrm{ppm}$ (corresponding to the formation of 7) was also obtained by mixing 5 and 2 equiv of $\left[\operatorname{Sn}(\mathrm{O} i \operatorname{Pr})_{2}\right]_{2}(\mathbf{3})$. Attempts to establish clearly the origin of these resonances were unsuccessful, but they probably relate to bimetallic species of the type $\left[\mathrm{Sn}_{2}(\mathrm{OiPr})\left(\mathrm{N}\left(\mathrm{SiMe}_{3}\right)_{3}\right]\right.$ and $\left[\mathrm{Sn}_{2}(\mathrm{O} i \mathrm{Pr})_{3}\left(\mathrm{~N}\left(\mathrm{SiMe}_{3}\right)\right]\right.$, or even higher mixed tin(II) aggregates.

Complex 7 catalyzes ROP reactions without added alcohol. The Schlenk-scale ROP of L-LA at $60{ }^{\circ} \mathrm{C}$ initiated by 7 is controlled and gives $84 \%$ isolated yield after $4 \mathrm{~h}\left([\mathrm{~L}-\mathrm{LA}]_{\mathrm{T}} /[\mathrm{Sn}]_{\mathrm{T}}=25: 1\right.$, $[\mathrm{L}-\mathrm{LA}]_{\mathrm{T}}=0.75 \mathrm{M}, M_{\mathrm{n}, \text { theo }}=3,100 \mathrm{~g} \cdot \mathrm{mol}^{-1} ; M_{\mathrm{n}, \mathrm{NMR}}=4,500 \mathrm{~g} \cdot \mathrm{mol}^{-1} ; M_{\mathrm{n}, \mathrm{SEC}}=5,300 \mathrm{~g} \cdot \mathrm{mol}^{-1}, M_{\mathrm{w}} / M_{\mathrm{n}}$ = 1.17). End-group analysis by ${ }^{1} \mathrm{H}$ NMR spectroscopy and MALDI-ToF MS shows that $\mathrm{O} i \mathrm{Pr}$ is the 
sole initiating group in ROP reactions catalyzed by 7. During kinetically monitored polymerizations performed under identical conditions, the rate of reaction measured for $7\left(k_{\text {obs }}=15.1 \pm 0.1 \times 10^{-4}\right.$ $\mathrm{s}^{-1}$ and $k_{\mathrm{p}}=15.7 \pm 0.1 \times 10^{-2} \mathrm{~L} \cdot \mathrm{mol}^{-1} \cdot \mathrm{s}^{-1}$ ) matches that measured for 5/1-2 $i$ PrOH (Table 2). ${ }^{119} \mathrm{Sn}\left\{{ }^{1} \mathrm{H}\right\}$ NMR spectroscopy proved informative on the speciation of the 5/1-2 $\mathrm{iPrOH}$ system.

Addition of 10 equiv of $i \mathrm{PrOH}$ to $5\left(\delta_{119 \mathrm{Sn}}=+776.0 \mathrm{ppm}\right)$, i.e. under conditions pertaining to immortal ROP reactions, generates quantitatively the expected bis(isopropoxide) 3 (broad resonance at $\left.\delta_{119 \mathrm{Sn}}=c a .-195 \mathrm{ppm}\right)$, and indeed kinetic measurement for immortal polymerizations showed that $5+10 i \operatorname{PrOH}\left(k_{\mathrm{obs}}=18.7 \times 10^{-4} \mathrm{~s}^{-1}, k_{\mathrm{p}}=17.49 \pm 0.05 \times 10^{-2} \mathrm{~L}_{\mathrm{mol}}{ }^{-1} \cdot \mathrm{s}^{-1}\right)$ catalyzed the reaction with rates very similar to $3+8 i \mathrm{PrOH}\left(k_{\mathrm{obs}}=22.7 \times 10^{-4} \mathrm{~s}^{-1}, k_{\mathrm{p}}=25.86 \pm 0.16 \times 10^{-2}\right.$ $\left.\mathrm{L} \cdot \mathrm{mol}^{-1} \cdot \mathrm{s}^{-1}\right)$. Relevant ${ }^{119} \mathrm{Sn}\left\{{ }^{1} \mathrm{H}\right\} \mathrm{NMR}$ data are given in the Supporting Information (Figure S15).

The above kinetic, synthetic and spectroscopic data and the previously demonstrated ability of excess $i \mathrm{PrOH}$ to displace phenolic ligands from aminoether-phenolate heteroleptic complexes $\left\{\mathrm{LO}^{i}\right\} \mathrm{Sn}(\mathrm{O} i \mathrm{Pr})$ show that provided the alcohol concentration is sufficiently high - typically 7 equiv or more vs. $\mathrm{Sn}(\mathrm{II})-$ all catalyst precursors 1-5 generate the same active species, namely the homoleptic $\mathrm{Sn}(\mathrm{OiPr})_{2}$, at a rate which depends on the presence and nature of the ancillary phenolate ligand. All eventually polymerize L-LA at about the same rate under immortal conditions (Scheme 3 and Figure 5). Since initiation cannot be detected with 3 (the fastest catalyst), it appears reasonable to infer that the initiation observed in some cases for ROP reactions catalyzed by our tin(II) precatalysts in the presence of excess alcohol $\left(k_{\mathrm{i}}<k_{\mathrm{p}}\right.$ in Table 1$)$ results from slow formation of $\left\{\mathrm{LO}^{i}\right\} \mathrm{Sn}(\mathrm{O} i \mathrm{Pr})$ and/or $\mathrm{Sn}(\mathrm{O} i \mathrm{Pr})_{2 .}{ }^{25}$ An identical phenomenon was observed by Duda and Penczek in their studies of ROP reactions (lactide, $\varepsilon$-caprolactone) catalyzed by the binary system $\mathrm{Sn}$ (2-ethyl-hexanoate $)_{2}+n \mathrm{BuOH} .{ }^{9 \mathrm{a}-\mathrm{b}}$ Although the mechanisms of formation of the active species were not investigated, these authors demonstrated that polymerization rates increased with $[n \mathrm{BuOH}]_{\mathrm{T}}$ until it reached a plateau for $[n \mathrm{BuOH}]_{\mathrm{T}} /[\mathrm{Sn}]_{\mathrm{T}}=5-10$ and showed by MALDI-ToF mass spectrometry that several active species, namely (2-ethyl-hexanoate) $\operatorname{Sn}(\mathrm{On} \mathrm{Bu}), \mathrm{Sn}(\mathrm{OnBu})_{2}$, and (2- 
ethyl-hexanoate) $\mathrm{SnOSn}(\mathrm{O} n \mathrm{Bu})$, were all found in the reaction medium when excess $n \mathrm{BuOH}$ was used.

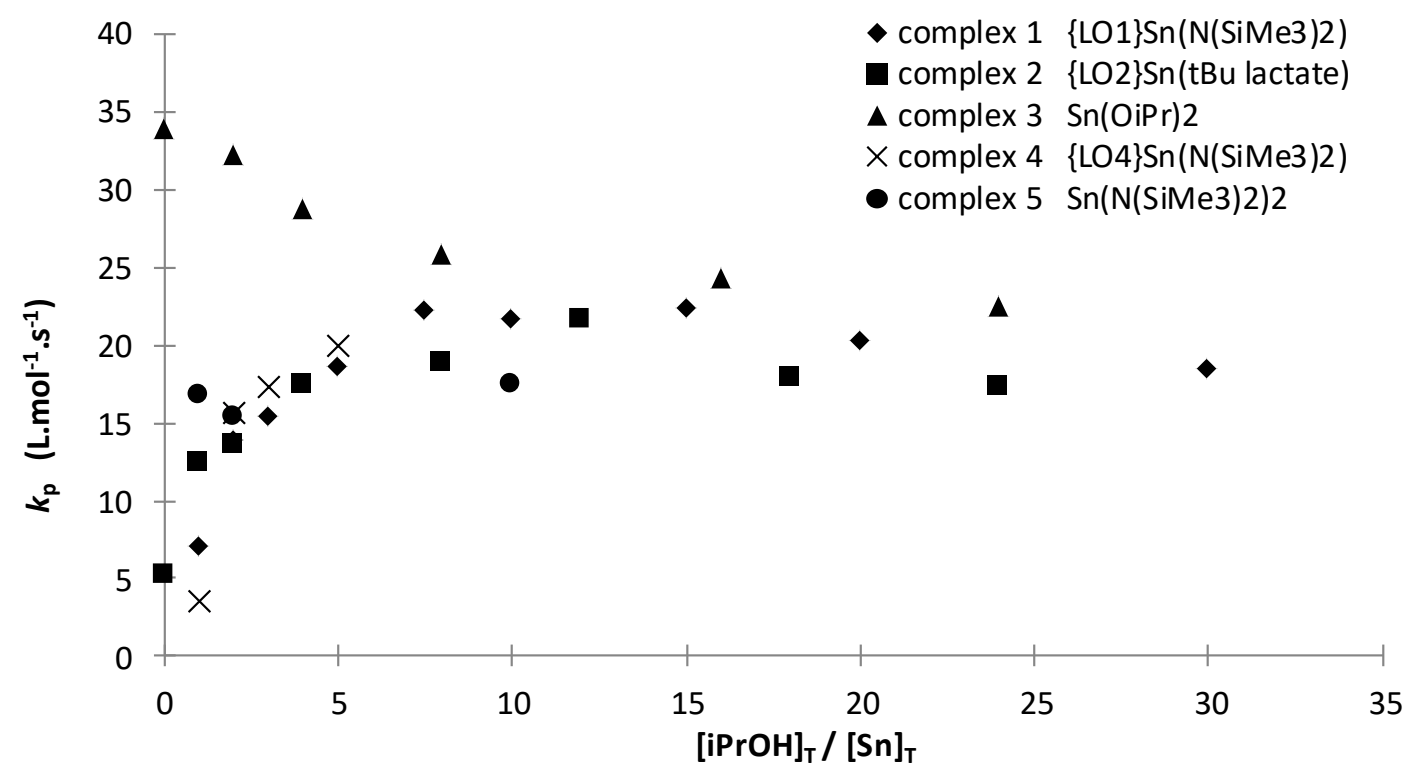

Figure 5. Variation of $k_{\mathrm{p}}$ with the ratio $[i \mathrm{PrOH}]_{\mathrm{T}} /[\mathrm{Sn}]_{\mathrm{T}}$ for the immortal ROP of L-lactide catalyzed by 1-5. Polymerization in toluene- $d_{8},[\mathrm{Sn}]_{\mathrm{T}}=10 \mathrm{mM},[\mathrm{L}-\mathrm{LA}]_{\mathrm{T}}=1.00 \mathrm{M}$, and $T=60^{\circ} \mathrm{C}$.
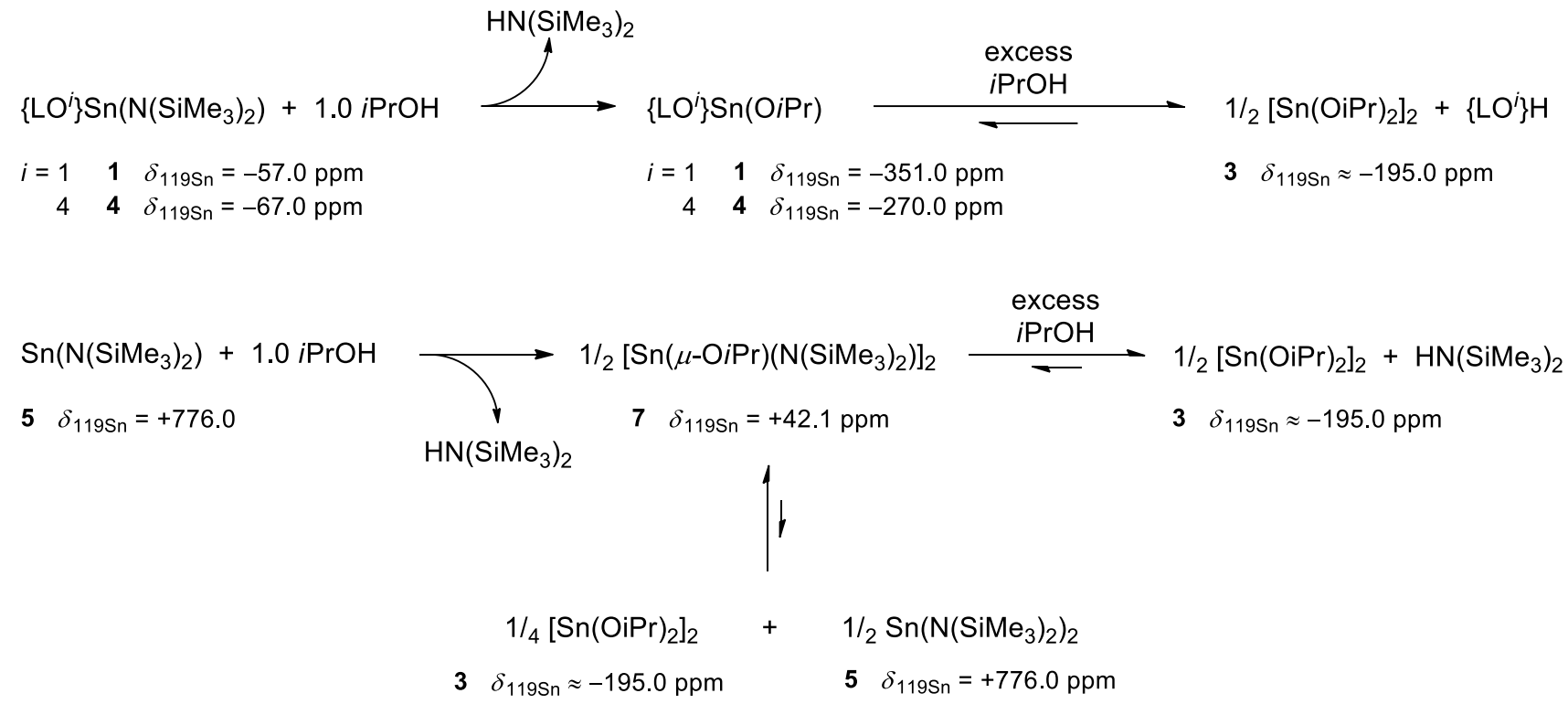

\section{Scheme 3.}




\section{Conclusion}

A detailed kinetic analysis of the early stage of immortal ring-opening polymerization reactions catalyzed by a metal catalyst precursor and a chain transfer agent has been developed. Curve fitting to this kinetic scheme allows the extraction of initiation and propagation rate constants, $k_{\mathrm{i}}$ and $k_{\mathrm{p}}$ respectively. Systems showing the scenarios $k_{\mathrm{i}}<k_{\mathrm{p}}, k_{\mathrm{i}}=k_{\mathrm{p}}$ and $k_{\mathrm{i}}>k_{\mathrm{p}}$ have been identified. The results confirm that the rate of chain exchange under immortal conditions is much faster than propagation, but it is not directly accessible by this method. Future efforts are aimed at developing a model that can also describe the distribution of molecular weights and thus access lower estimates of $k_{\mathrm{e}}$ values. For a given catalytic system, the values of $k_{\mathrm{i}}$ (if it can be measured) and $k_{\mathrm{p}}$ can be extracted from a single experiment using the present kinetic treatment, whereas other methods require multiple experiments. ${ }^{2 r, 7,11 a, 13,26}$

ROP catalysis mediated by group 14 complexes proceeds at a convenient rate to illustrate the model, comparing the values of $k_{\mathrm{p}}$ determined independently either using eq (4) or conventionally by steady-state methods, which are found to be in good agreement.

While the kinetic model enables the detection and quantification of an initiation period, it cannot provide direct evidence for the molecular process of initiation. There may be different reasons for the initiation phase observed for various catalysts (e.g. slow generation of a reactive metal-nucleophile species, catalyst aggregation, slow first monomer insertion...), but in all cases slow initiation points to mechanistic implications that need to be taken into account for a complete description of the immortal ROP process. In the present case of $\mathrm{Sn}(\mathrm{II})$ catalysts we propose that initiation is linked to the rate of generation of a mononuclear tin(II) alkoxide species in the presence of excess alcohol.

While tin(II) catalysts and L-lactide proved convenient to demonstrate its validity, the proposed kinetic model is of course general in nature and equally applicable to other substrates such as trimethylene carbonate and other catalysts. In situ FTIR techniques are able to record monomer conversion for systems that are too fast for conventional NMR techniques, and we are now planning 
to implement these methods to the very active rare- and alkaline-earth ROP catalysts. The model proposed here will hopefully enable rapid and unambiguous comparisons of the efficiencies of ROP catalysts.

Our treatment relies only on general principles and includes the initiation stage of the reaction as a key part of the analysis. It comes as a complementary addition to the useful MichaelisMenten-like kinetic treatment recently reported by Tolman and Hillmyer. ${ }^{13}$ The question of equilibria between aggregated and non-aggregated metal species remains. This will require additional investigations for a wider range of systems, but is of limited importance here since most well-defined ROP precatalysts (as opposed to $\mathrm{Sn}^{\mathrm{II}}(2 \text {-ethyl-hexanoate) })_{2}$ ) are known to produce monometallic active species under polymerization conditions, ${ }^{3,11,27}$ even when the precatalyst is dimeric in the solid-state or in solution. ${ }^{12}$

Specific features of tin(II)-mediated ROP catalysis have also become apparent. Reversible generation of tin(II) bis(alkoxide) has been demonstrated by ${ }^{119} \operatorname{Sn}\left\{{ }^{1} \mathrm{H}\right\}$ NMR studies when a small excess of alcohol is used with these tin(II) precatalysts, and this is consistent with the kinetic data recorded for $\left\{\mathrm{LO}^{i}\right\} \mathrm{Sn}\left(\mathrm{N}\left(\mathrm{SiMe}_{3}\right)_{2}\right), \mathrm{Sn}(\mathrm{OiPr})_{2}, \mathrm{Sn}(\mathrm{OiPr})\left(\mathrm{N}\left(\mathrm{SiMe}_{3}\right)_{2}\right.$ and $\mathrm{Sn}\left(\mathrm{N}\left(\mathrm{SiMe}_{3}\right)_{2}\right)_{2}$ in the presence of excess alcohol. Based on the present and our earlier study, ${ }^{11 \mathrm{a}}$ it is now established that with all these $\mathrm{Sn}(\mathrm{II})$ precatalysts, $\mathrm{Sn}(\mathrm{O} i \mathrm{Pr})_{2}$ and $\mathrm{Sn}(\mathrm{O} \text {-polymeryl })_{2}$ are the actual catalytically initiating and propagating species in immortal ROP reactions when a large excess of alcohol, typically 7 equiv or more, is employed.

\section{Experimental Section}

General procedures. All manipulations were performed under inert atmosphere using standard Schlenk techniques or in a glove-box. $\left\{\mathrm{LO}^{1}\right\} \mathrm{Sn}\left(\mathrm{N}\left(\mathrm{SiMe}_{3}\right)_{2}\right)(\mathbf{1}),{ }^{11 \mathrm{a}}\left\{\mathrm{LO}^{2}\right\} \mathrm{Sn}(t \mathrm{Bu}(R)-$ lactate $)(\mathbf{2}),{ }^{11 \mathrm{~b}}$ $\left[\mathrm{Sn}(\mathrm{OiPr})_{2}\right]_{2}(\mathbf{3}),{ }^{12}\left\{\mathrm{LO}^{4}\right\} \mathrm{Sn}\left(\mathrm{N}\left(\mathrm{SiMe}_{3}\right)_{2}\right)(\mathbf{4}),{ }^{11 \mathrm{~b}} \mathrm{Sn}\left(\mathrm{N}\left(\mathrm{SiMe}_{3}\right)_{2}\right)_{2}(\mathbf{5})^{28}$ and $\left\{\mathrm{LO}^{1}\right\} \mathrm{Ge}\left(\mathrm{N}\left(\mathrm{SiMe}_{3}\right)_{2}(\mathbf{6})^{10 \mathrm{~g}}\right.$ were prepared as reported. THF was distilled under argon from Na/benzophenone prior to use. Other solvents were collected from MBraun SPS-800 purification alumina columns. Deuterated 
solvents were stored in sealed ampoules over activated $3 \AA$ molecular sieves and degassed by several freeze-thaw cycles. L-LA (Total Petrochemicals) was purified by recrystallisation from a hot $\left(80{ }^{\circ} \mathrm{C}\right) i \mathrm{PrOH}$ solution, followed by two recrystallisations in hot $\left(105{ }^{\circ} \mathrm{C}\right)$ toluene. TMC (Bohringer) was dissolved in THF, dried over $\mathrm{CaH}_{2}$ and recrystallised from THF prior to use.

NMR spectra were recorded on Bruker AM-400 and AM-500 spectrometers. The probe temperature was regularly checked by standard methods relying on methanol (180-300 K) and ethylene glycol (300-380 K) solutions. All ${ }^{1} \mathrm{H}$ and ${ }^{13} \mathrm{C}\left\{{ }^{1} \mathrm{H}\right\}$ chemical shifts were determined using residual signals of the deuterated solvents. ${ }^{119} \mathrm{Sn}\left\{{ }^{1} \mathrm{H}\right\}$ NMR spectra were calibrated vs. $\mathrm{SnMe}_{4}$.

Typical NMR-scale polymerization procedure. Immortal ROP reactions were systematically conducted in toluene- $d_{8}$. In a typical experiment, the catalyst and monomer were loaded in an NMR tube in the glove-box. The NMR tube was placed in a Schlenk flask, which was then removed from the glove-box and connected to the vacuum manifold. All subsequent operations were performed using Schlenk techniques. The appropriate amounts of solvent (toluene- $\left.d_{8}\right)$ and activator $(i \mathrm{PrOH})$ were added to the NMR tube in this order at room temperature. The NMR tube was then sealed, briefly and very gently heated to ensure complete dissolution of the monomer and introduced in the spectrometer pre-set at the desired temperature $\left(25,45,60,70\right.$ or $\left.100{ }^{\circ} \mathrm{C}\right)$. Time measurement started at this point. Data points were collected at regular intervals (typically 15-60 s), with a relaxation delay time sufficient to ensure accurate integration (D1 $=0.5 \mathrm{~s}$ ) and NS $=8$ scans until conversion of the monomer stopped (this usually coincided with near-full conversion). The conversion was reliably determined by integrating the methine region of PLLA $\left(\delta_{1 \mathrm{H}} 5.00 \mathrm{ppm}\right.$ at 60 ${ }^{\circ} \mathrm{C}$ in toluene- $\left.d_{8}\right) v s$. that of the monomer $\left(\delta_{1 \mathrm{H}} 4.08 \mathrm{ppm}\right.$ at $60{ }^{\circ} \mathrm{C}$ in toluene- $\left.d_{8}\right)$. The accuracy of the measurements was corroborated by the good agreement between theoretical (based on the conversion, $M_{\mathrm{n} \text {,theo }}=144.13 \times[\mathrm{L}-\mathrm{LA}]_{\mathrm{T}} /[i \operatorname{PrOH}]_{\mathrm{T}} \times$ conversion $)$ and experimental $\left(M_{\mathrm{n}, \mathrm{NMR}}\right.$ determined by integration of the resonance of the methine hydrogens $v s$. that of the chain-ends) molecular weights. Reproducibility between identical runs was assessed under various conditions 
and proved excellent; hence viscosity and potential mass transfer limitations have not been considered a potential source of error in kinetic measurements.

Typical Schlenk-scale polymerization procedure. In the glove-box, the metal catalyst ( $c a$. 2.5-5.0 mg) was placed in a Schlenk flask together with the monomer ( $c a .0 .5-1.5 \mathrm{~g})$. The Schlenk flask was sealed and removed from the glove box. All subsequent operations were carried out on a vacuum manifold using Schlenk techniques. The required amount of solvent (toluene) was added by syringe to the catalyst and the monomer, followed when required by addition of the activator ( $i \mathrm{PrOH}, 3-10 \mu \mathrm{L}$ ). The resulting mixture was immersed in an oil bath pre-set at the desired temperature $\left(60^{\circ} \mathrm{C}\right)$ and the polymerization time was measured from this point. Concentrations of L-lactide were in the range $1.0-2.0 \mathrm{M}$; complete dissolution was rapidly achieved upon vigorous stirring under the chosen experimental conditions. The reaction was terminated by addition of acidified $\mathrm{MeOH}(\mathrm{HCl}, 1 \mathrm{wt}-\%)$ and the polymer was precipitated in methanol and washed thoroughly. The polymer was then dried to constant weight in a vacuum oven at $55{ }^{\circ} \mathrm{C}$ under dynamic vacuum $\left(<5 \times 10^{-2}\right.$ mbar $)$.

Curve-fitting methods. Non-linear regressions using equation (4) were performed with the software DataFit 9.0. The concentration of enchained monomer $[\mathrm{M}]_{\mathrm{B}}$ was calculated according to $[\mathrm{M}]_{\mathrm{B}}=[\mathrm{M}]_{\mathrm{T}} \times$ conversion, using data points collected for conversion typically below $25 \%$. Curve fittings were performed using a fixed value of $k_{\mathrm{e}}$ set at $100 \mathrm{~L} \cdot \mathrm{mol}^{-1} \cdot \mathrm{s}^{-1}$. A time correction variable was introduced during the processing of curve-fitting experiment to stand for the time interval required by the reaction mixture in the NMR tube to reach temperature equilibration once inside the probe of the NMR spectrometer.

\section{- ASSOCIATED CONTENT}

*SI Supporting Information 
Details of the kinetic analysis; experimental and spectroscopic data on precatalyst 7, data on polymer analysis. This material is available free of charge via the Internet at http://pubs.acs.org.

\section{- AUTHOR INFORMATION}

Corresponding Author

*Tel: +33 223233 019. E-mail: yann.sarazin@univ-rennes1.fr

Notes

The authors declare no competing financial interest.

\section{- ACKNOWLEDGMENTS}

Assistance from Sourisak Sinbandhit $\left({ }^{119} \mathrm{Sn}\left\{{ }^{1} \mathrm{H}\right\}\right.$ NMR; Centre Régional des Mesures Physiques de l'Ouest, University of Rennes), Vincent Dorcet (X-ray diffraction crystallography, Institut des Sciences Chimiques de Rennes), Stephen Boyer (elemental analysis; London Metropolitan University), Jean-Paul Guégan (DOSY measurements; Institut des Sciences Chimiques de Rennes) and Total Petrochemicals (grant to V. P.) is gratefully acknowledged.

\section{- REFERENCES}

1 (a) Uhrich, K. E.; Cannizzaro, S. M.; Langer, R. S.; Shakesheff, K. M. Chem. Rev. 1999, 99, 3181. (b) Mecking, S. Angew. Chem. Int. Ed. 2004, 43, 1078. (c) Handbook of Ring-Opening Polymerization, Wiley-VCH, Eds: Dubois, P.; Coulembier, O.; Raquez, J.-M., Weinheim, 2009. (d) Poly(lactic acid): Synthesis, Structures, Properties, Processing and Applications, John Wiley and Sons Inc., Eds: Auras, R.; Lim, L.-T.; Selke, S. E. M.; Tsuji, H., Hoboken, New Jersey, 2010.

2 (a) Ovitt, T. M.; Coates, G. W. J. Am. Chem. Soc. 1999, 121, 4072. (b) Cheng, M.; Attygalle, A. B.; Lobkovsky, E. B.; Coates, G. W. J. Am. Chem. Soc. 1999, 121, 11583. (c) Chamberlain, B. M.; Cheng, M.; Moore, D. R.; Ovitt, T. M.; Lobkovsky, E. B.; Coates, G. W. J. Am. Chem. Soc. 2001, 123, 3229. (d) Ko, B.-T.; Lin, C.-C. J. Am. Chem. Soc. 2001, 123, 7973. (e) Ovitt, T. M.; Coates, G. W. J. Am. Chem. Soc. 2002, 124, 1316. (f) Nomura, N.; 
Ishii, R.; Akakura, M.; Aoi, K. J. Am. Chem. Soc. 2002, 124, 5938. (g) Williams, C. K.; Breyfogle, L. E.; Choi, S. K.; Nam, W.; Young Jr., V. G.; Hillmyer, M. A.; Tolman, W. B. J. Am. Chem. Soc. 2003, 125, 11350. (h) Cai, C.-X.; Amgoune, A.; Lehmann, C. W.; Carpentier, J.-F. Chem. Commun. 2004, 330. (i) Majerska, K.; Duda, A. J. Am. Chem. Soc. 2004, 126, 1026. (j) Hormnirun, P.; Marshall, E. L.; Gibson, V. C.; White, A. J. P.; Williams, D. J. J. Am. Chem. Soc. 2004, 126, 2688. (k) Dove, A. P.; Gibson, V. C.; Marshall, E. L.; Rzepa, H. S.; White, A. J. P.; Williams, D. J. J. Am. Chem. Soc. 2006, 128, 9834. (1) Ma, H.; Spaniol, T. P.; Okuda, J. Angew. Chem. Int. Ed. 2006, 45, 7818. (m) Chmura, A. J.; Chuck, C. J.; Davidson, M. G.; Jones, M. D.; Lunn, M. D.; Bull, S. D.; Mahon, M. F. Angew. Chem. Int. Ed. 2007, 46, 2280. (n) Douglas, A. F.; Patrick, B. O.; Mehrkhodavandi, P. Angew. Chem. Int. Ed. 2008, 47, 2290. (o) Otero, A.; Fernández-Baeza, J.; Lara-Sánchez, A.; Alonso-Moreno, C.; MárquezSegovia, I.; Sánchez-Barba, L. F.; Rodríguez, A. M. Angew. Chem. Int. Ed. 2009, 48, 2176. (p) N. Nomura, A. Akita, R. Ishii, M. Mizuno, J. Am. Chem. Soc. 2010, 132, 1750. (q) Pietrangelo, A.; Knight, S. C.; Gupta, A. K.; Yao, L. J.; Hillmyer, M. A.; Tolman, W. B. J. Am. Chem. Soc. 2010, 132, 11649. (r) Sarazin, Y.; Liu, B.; Roisnel, T.; Maron, L.; Carpentier, J.-F. J. Am. Chem. Soc. 2011, 133, 9069. (s) Bakewell, C.; Cao, T.-P.-A.; Long, N.; Le Goff, X. F.; Auffrant, A.; Williams, C. K. J. Am. Chem. Soc. 2012, 134, 20577.

3 (a) Dechy-Cabaret, O.; Martin-Vaca, B.; Bourissou, D. Chem. Rev. 2004, 104, 6147. (b) Williams, C. K.; Hillmyer, M. A. Polym. Rev. 2008, 48, 1. (c) Wheaton, C. A.; Hayes, P. G.; Ireland, B. J. Dalton Trans. 2009, 4832. (d) Ajellal, N.; Carpentier, J.-F.; Guillaume, C.; Guillaume, S. M.; Hélou, M.; Poirier, V.; Sarazin, Y.; Trifonov, A. Dalton Trans. 2010, 39, 8363. (e) Thomas, C. M. Chem. Soc. Rev. 2010, 39, 165. (f) Stanford, M. J.; Dove, A. P. Chem. Soc. Rev. 2010, 39, 486. (g) Dijkstra, P. J.; Du, H.; Feijen, J. Polym. Chem. 2011, 2 , 520. (h) Dagorne, S.; Normand, M.; Kirillov, E.; Carpentier, J.-F. Coord. Chem. Rev. 2013, 257, 1869. (i) Sauer, A.; Kapelski, A.; Fliedel, C.; Dagorne, S.; Kol, M.; Okuda J. Dalton Trans. 2013, 42, 9007.

(a) Asano, S.; Aida, T.; Inoue, S. J. Chem. Soc., Chem. Commun. 1985, 1148. (b) Aida, T.; Inoue, S. Acc. Chem. Res. 1996, 29, 39.

5 In accordance with the common terminology used in the literature, the term "immortal" polymerization is employed here to designate controlled living ROP reactions performed in the presence of excess exogenous transfer agent such an alcohol ( $\mathrm{PrOH}$ in our case) or an amine, with fast and reversible exchange between active and dormant macromolecules; see for instance ref. $3 \mathrm{~d}$ and 4. 
(a) Liu, B.; Roisnel, T.; Maron, L.; Carpentier, J.-F.; Sarazin, Y. Chem. Eur. J. 2013, 19, 3986. (b) Clark, L.; Deacon, G. B.; Forsyth, C. M.; Junk, P. C.; Mountford, P.; Townley, J. P.; Wang J. Dalton Trans. 2013, 42, 9294.

7 For representative applications, see references 2d, 2r, 6 and: (a) Martin, E.; Dubois, P.; Jérôme, R. Macromolecules 2000, 33, 1530. (b) Liu, Y.-C.; Ko, B.-T.; Lin, C.-C. Macromolecules 2001, 34, 6196. (c) Shueh, M.-L.; Wang, Y.-S.; Huang, B.-H.; Kuo, C.-Y.; Lin, C.-C. Macromolecules 2004, 37, 5155. (d) Amgoune, A.; Thomas, C. M.; Carpentier, J.F. Macromol. Rapid Commun. 2007, 28, 693. (e) Poirier, V.; Roisnel, T.; Carpentier, J.-F.; Sarazin, Y. Dalton Trans. 2009, 9820. (f) Clark, L.; Cushion, M. G.; Dyer, H. E.; Schwarz, A. D.; Duchateau, R.; Mountford, P. Chem. Commun. 2010, 46, 273. (g) Zhao, W.; Cui, D.; Liu, X.; Chen, X. Macromolecules 2010, 43, 6678. (h) Hild, F.; Brelot, L.; Dagorne, S. Organometallics 2011, 30, 5457. (i) Cushion, M. G.; Mountford, P. Chem. Commun. 2011, 47, 2276. (j) Wang, Y.; Zhao, W.; Liu, X.; Cui, D.; Chen, E. Y.-X. Macromolecules 2012, 45, 6957. (k) Wang, Y.; Ma H. Chem. Commun. 2012, 48, 6729. (l) Li, G.; Lamberti, M.; Mazzeo, M.; Pappalardo, D.; Roviello, G.; Pellecchia, C. Organometallics 2012, 31, 1180. (m) Lamberti, M.; D’Auria, I.; Mazzeo, M.; Milione, S.; Bertolasi, V.; Pappalardo, D. Organometallics 2012, 31, 5551. (n) Liu, B.; Roisnel, T.; Guégan, J.-P.; Carpentier, J.-F.; Sarazin, Y. Chem. Eur. J. 2012, 18, 6289. (o) Zhao, W.; Wang, Y.; Liu, X.; Chen, X.; Cui, D. Chem. Asian J. 2012, 7, 2403. (p) Zhao, W.; Wang, Y.; Liu, X.; Cui, D. Chem. Commun. 2012, 48, 4483. (q) Zhao, W.; Wang, Y.; Liu, X.; Chen, X.; Cui, D.; Chen, E. Y.-X. Chem. Commun. 2012, 48, 6375. (r) Xu, C.; Yu, I.; Mehrkhodavandi, P. Chem. Commun. 2012, 48, 6806. (s) Li, C.-Y.; Wu, C.-R.; Liu, Y.-C.; Ko, B.-T. Chem. Commun. 2012, 48, 9628. (t) Hild, F.; Neehaul, N.; Bier, F.; Wirsum, M.; Gourlaouen, C.; Dagorne, S. Organometallics 2013, 32, 587.

8 See for instance: (a) Shan, J.; Haerkoenen, M.; Ropponen, J.; Harlin, A.; Heikkinen, H.; Raemoe, V.; Gaedda, T.; Nurmi, L.; Willberg-Keyrilaeinen, P. PCT Int. Appl. 2012, WO 2012/160258. (b) Slawinski, M.; Hélou, M.; Wassenaar, J. PCT Int. Appl. 2013, WO 2013/087812.

9 (a) Duda, A.; Penczek, S. Macromolecules 1990, 23, 1636. (b) Kowalski, A; Duda, A.; Penczek, S. Macromol. Rapid Commun. 1998, 19, 567. (c) Kowalski, A.; Duda, A.; Penczek S. Macromolecules 2000, 33, 689. (d) Kricheldorf, H. R.; Kreiser-Saunders, I.; Stricker, A. Macromolecules 2000, 33, 702. (e) Kowalski, A.; Libiszowski, J.; Duda, A.; Penczek, S. Macromolecules 2000, 33, 1964. (f) Kowalski, A.; Duda, A.; Penczek, S., Macromolecules 2000, 33, 7359. (g) Penczek, S.; Duda, A.; Kowalski, A.; Libiszowski, J.; Majerska, K.; Biela, 
T. Macromol. Symp. 2000, 157, 61. (h) Biela, T.; Duda, A.; Penczek, S. Macromol. Symp. 2002, 183, 1. (i) Kowalski, A.; Libiszowski, J.; Biela, T.; Cypryk, M.; Duda, A.; Penczek, S. Macromolecules 2005, 38, 8170.

10 (a) Dove, A. P.; Gibson, V. C.; Marshall, E.L.; White, A. J. P.; Williams, D. J. Chem. Commun. 2001, 283. (b) Aubrecht, K. B.; Hillmyer, M. A.; Tolman, W. B. Macromolecules 2002, 35, 644. (c) Nimitsiriwat, N.; Marshall, E. L.; Gibson, V. C.; Elsegood, M. R. J.; Dale, S. H. J. Am. Chem. Soc. 2004, 126, 13598. (d) Nimitsiriwat, N.; Gibson, V. C.; Marshall, E. L.; White, A. J. P.; Dale, S. H.; Elsegood, M. R. J. Dalton Trans. 2007, 4464. (e) Nimitsiriwat, N.; Gibson, V. C.; Marshall, E. L.; Elsegood, M. R. J. Inorg. Chem. 2008, 47, 5417. (f) Nimitsiriwat, N.; Gibson, V.C.; Marshall, E. L.; Elsegood, M. R. J. Dalton Trans. 2009, 3710. (g) Wang, L.; Roşca, S.-C.; Poirier, V.; Sinbandhit, S.; Dorcet, V.; Roisnel, T.; Carpentier, J.-F.; Sarazin Y. Dalton Trans. 2014, 43, 4268.

11 (a) Poirier, V.; Roisnel, T.; Sinbandhit, S.; Bochmann, M.; Carpentier, J.-F.; Sarazin, Y. Chem. Eur. J. 2012, 18, 2998. (b) Wang, L.; Kefalidis, C. E.; Sinbandhit, S.; Dorcet, V.; Carpentier, J.-F.; Maron, L.; Sarazin, Y. Chem. Eur. J. 2013, 19, 13463.

12 Wang, L.; Bochmann, M.; Cannon, R. D.; Carpentier, J.-F.; Roisnel, T.; Sarazin, Y. Eur. J. Inorg. Chem, 2013, 5896.

13 (a) Ding, K.; Miranda, M. O.; Moscato-Goodpaster, B.; Ajellal, N.; Breyfogle, L. E.; Hermes, E. D.; Schaller, C. P.; Roe, S. E.; Cramer, C. J.; Hillmyer, M. A.; Tolman, W. B. Macromolecules 2012, 45, 5387. (b) Miranda, M. O.; DePorre, Y.; Vazquez-Lima, H.; Johnson, M. A.; Marell, D. J.; Cramer, C. J.; Tolman, W. B. Inorg. Chem. 2013, 52, 13692.

14 For reviews, see: (a) Bochmann, M. J. Organomet. Chem. 2004, 689, 3982. (b) M. Bochmann, Organometallics 2010, 29, 4711. See also: (c) Liu, Z.; Somsook, E.; Landis, C. R. J. Am. Chem. Soc. 2001, 123, 2915. (d) Liu, Z.; Somsook, E.; White, C. B.; Rosaaen, K. A.; Landis, C. R. J. Am. Chem. Soc. 2001, 123, 11193. (e) Sillars, D. R.; Landis, C. R. J. Am. Chem. Soc. 2003, 125, 9894. (f) Song, F.; Cannon, R. D.; Lancaster, S. J.: Bochmann, M. J. Mol. Catal. 2004, 218, 21.

15 Note that in Carother's theory for step-growth polymerizations, the reactivity of functional groups is independent of the molecule size. See: Principles of Polymerization, Fourth Edition; G. Odian, John Wiley and Sons Inc., Hoboken, New Jersey, 2004.

16 Zinc, alkaline- and rare-earth precatalysts are too fast for kinetic monitoring by ${ }^{1} \mathrm{H}$ NMR, while $\mathrm{Li}$ - and Al-based ones are too slow. See for instance references $7 \mathrm{~d}-\mathrm{f}$ and $7 \mathrm{n}$.

17 If this value was not set initially, i.e. when $k_{\mathrm{e}}$ was allowed to refine freely, the different software that we used (Origin, Matlab or DataFit) did not converge to a single solution. 
18 Changing $k_{\mathrm{e}}$ by 12 orders of magnitude had only marginal influence on the resulting values of $k_{\mathrm{p}}$ and $k_{\mathrm{i}}$. For ROP of L-LA catalyzed by $1 / i \mathrm{PrOH}$ at $25{ }^{\circ} \mathrm{C}$ with $[\mathrm{L}-\mathrm{LA}]_{\mathrm{T}} /[1]_{\mathrm{T}} /[i \mathrm{PrOH}]_{\mathrm{T}}=$ 66:1:5 (corresponding to entry 1 in Table 1 ), when $k_{\mathrm{e}}$ is deliberately fixed at values between $10^{-6}$ to $10^{6} \mathrm{~L} \cdot \mathrm{mol}^{-1} \cdot \mathrm{s}^{-1}, k_{\mathrm{p}}$ and $k_{\mathrm{i}}$ only vary from $1.09 \times 10^{-2}$ to $1.85 \times 10^{-2} \mathrm{~L} \cdot \mathrm{mol}^{-1} \cdot \mathrm{s}^{-1}$ and $3.73 \times 10^{-3}$ to $6.17 \times 10^{-3} \mathrm{~L} \cdot \mathrm{mol}^{-1} \cdot \mathrm{s}^{-1}$ respectively, i.e. the observed variations are kinetically insignificant. Similar results were observed when the value of $k_{\mathrm{e}}$ was tuned in the same manner for all other experiments taken from Table 1.

19 Polymerization conditions were similar to those for entries $12-13$ in Table $1: \mathrm{T}=60{ }^{\circ} \mathrm{C}$, [L$\mathrm{LA}]_{0}=1.0 \mathrm{M},[\mathrm{Sn}]_{\mathrm{T}}=2.50-50.0 \mathrm{mM}$. The intersection with the concentration axis was very close to zero, suggesting that minimal catalyst deactivation occurred through the presence of impurities. Details are available from the Supporting Information and ref. 12.

20 Under the experimental conditions of Table 1, the homoleptic bis(alkoxide) 3 generally proved much too fast to record data points in the early stage of the polymerization, which argues against the occurrence of a slow initiation step.

21 Pepels, M. P. F.; Bouyahyi, M.; Heise, A.; Duchateau, R. Macromolecules 2013, 46, 4324.

22 For a given catalyst precursor, one can generally define $[\text { polymer chains }]_{\mathrm{T}}=n \times[\mathrm{Sn}]_{\mathrm{T}}+$ $[i \mathrm{PrOH}]_{\mathrm{T}}$, where $n$ is the number of alkoxide group found in the initial complex: for $\mathbf{1}, n=0$; for $2, n=1$.

23 Both ${ }^{1} \mathrm{H}$ and ${ }^{119} \mathrm{Sn}\left\{{ }^{1} \mathrm{H}\right\}$ NMR spectroscopies show unequivocally the irreversible release of free $\mathrm{HN}\left(\mathrm{SiMe}_{3}\right)_{2}$ upon reaction of $\left\{\mathrm{LO}^{i}\right\} \mathrm{Sn}\left(\mathrm{N}\left(\mathrm{SiMe}_{3}\right)_{2}\right)$ and $i \mathrm{PrOH}$; see ref. 11 and present work. Also, kinetic data in Table 2 show that $(i) \mathrm{Sn}\left(\mathrm{N}\left(\mathrm{SiMe}_{3}\right)_{2}\right)$ is a very slow ROP initiator compared to $\mathrm{Sn}(\mathrm{O} i \mathrm{Pr})_{2}$, and (ii) the addition of 2-10 equiv of $\mathrm{HN}\left(\mathrm{SiMe}_{3}\right)_{2}$ to $\mathrm{Sn}(\mathrm{O} i \mathrm{Pr})_{2}$ does not affect the rate of the living ROP of L-LA catalyzed by the latter compound.

24 Similar observations have already been made before for other complexes, for instance by Gibson (ref. 10d) or by Tolman and Hillmyer: Aubrecht, K. B.; Chang, K.; Hillmyer, M. A.; Tolman, W. B. J. Polym. Sci., Polym. Chem. 2001, 39, 284.

25 It is in fact very likely that with these systems, the rate of initiation is directly related to the rate of formation of the reactive species. Several attempts to demonstrate this point by measuring the rate of formation of the tin(II)-alkoxide species under conditions related to ROP reactions have been made but failed due to experimental constraints.

26 Silvernail, C. M.; Yao, L. J.; Hill, L. M. R.; Hillmyer, M. A.; Tolman, W. B. Inorg. Chem. 2007, 46, 6565. 
27 (a) Chisholm, M. H.; Choojun, K.; Chow, A. S.; Fraenkel G. Angew. Chem. Int. Ed. 2013, 52, 3264. (b) Balasanthiran, V.; Chisholm, M. H.; Choojun, K.; Durr, C. B. Dalton Trans. 2014, $43,2781$.

28 Schaeffer, C. D.; Zuckerman, J. J. J. Am. Chem. Soc. 1974, 96, 7160.

\section{For the Table of Contents only:}

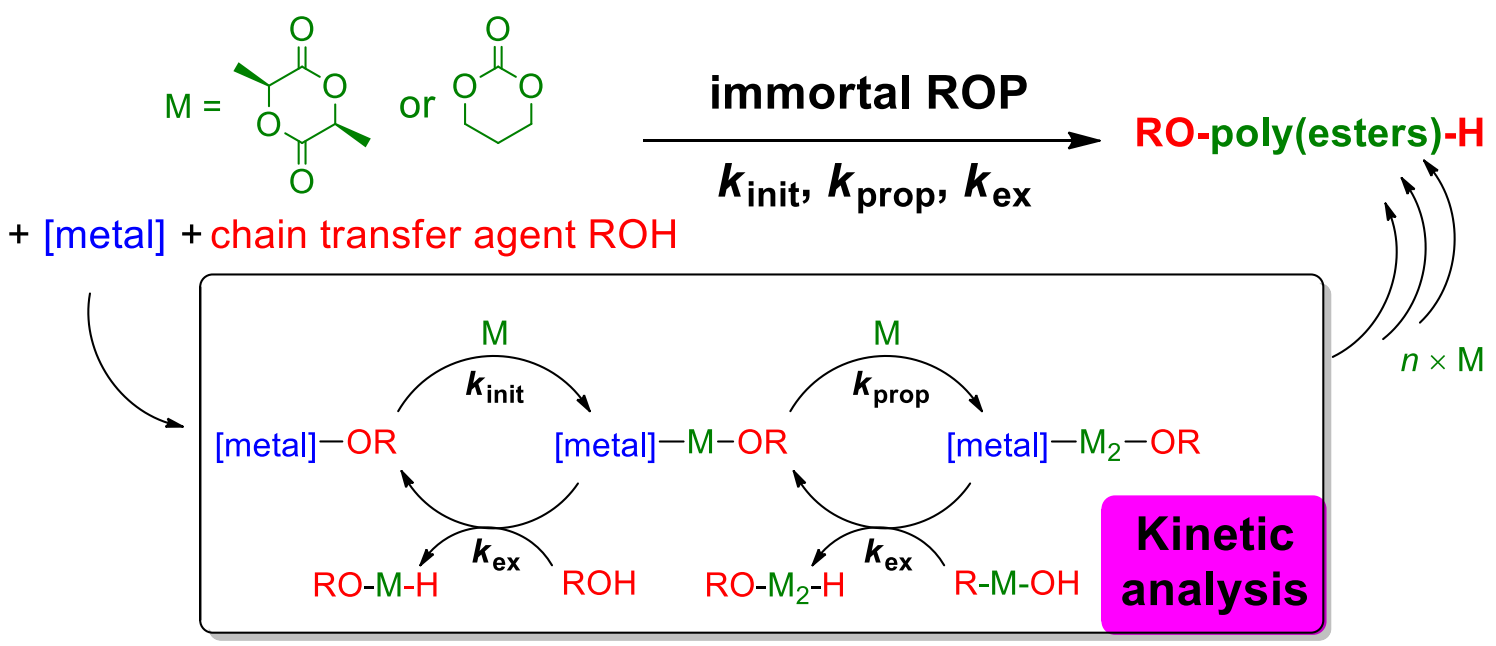

